\title{
Microwave-Assisted Passerini Reactions under Solvent-Free Conditions
}

\author{
Angélica de Fátima S. Barreto, Otilie E. Vercillo and Carlos Kleber Z. Andrade* \\ LaQMOS - Instituto de Química, Universidade de Brasília, CP 4478, 70910-970 Brasília-DF, Brazil
}

\begin{abstract}
Diversas $\alpha$-acilóxi carboxamidas foram facilmente obtidas combinando três componentes em uma única etapa: um ácido carboxílico, um aldeído e uma isonitrila (reação de Passerini), usando irradiação de micro-ondas em condições sem solvente. Os produtos foram obtidos em bons rendimentos $(61-90 \%)$ e em tempos reacionais bastante curtos $(\leq 5 \mathrm{~min})$, usando duas diferentes temperaturas $\left(60\right.$ e $\left.120^{\circ} \mathrm{C}\right)$. A $120^{\circ} \mathrm{C}$, os rendimentos foram mais altos e as reações mais rápidas ( $\leq 1 \mathrm{~min}$ ). Vários dos produtos formados são multifuncionais, possibilitando sua aplicação em reações de Passerini consecutivas.
\end{abstract}

\begin{abstract}
Various $\alpha$-acyloxy carboxyamides were easily obtained combining three building blocks in one step: a carboxylic acid, an aldehyde and an isonitrile (Passerini reaction), using microwave irradiation under solvent-free conditions. The products were obtained in good yields $(61-90 \%)$ and in short reaction times $(\leq 5 \mathrm{~min})$, using two different temperatures $\left(60\right.$ and $\left.120^{\circ} \mathrm{C}\right)$. At $120{ }^{\circ} \mathrm{C}$, the yields were higher and the reactions faster $(\leq 1 \mathrm{~min})$. Most of the obtained products are multifunctional allowing their application in consecutive Passerini reactions.
\end{abstract}

Keywords: $\alpha$-acyloxy carboxyamides, Passerini reaction, microwave irradiation, solvent-free reactions

\section{Introduction}

Multicomponent reactions (MCRs) are referred to as one-pot processes, where three or more reactants combine to give a single product which incorporates essentially most of the atoms of the starting materials. ${ }^{1}$ MCRs constitute an especially attractive synthetic strategy since they offer greater possibilities for molecular diversity per step with a minimum of synthetic effort, time and formation of by-products. ${ }^{2}$

The development of atom-economic and synthetically effective methodologies is currently an important goal in organic synthesis ${ }^{3}$ and in this regard MCRs play a significant role. At the same time, the use of microwave energy to facilitate chemical reactions has become increasingly popular in organic synthesis. ${ }^{4}$ Microwave-assisted organic synthesis (MAOS) has been demonstrated to be efficient at increasing the rate of MCR reactions with significant improvements in reaction times and yields. ${ }^{5}$

Combining these two powerful tools is a particularly attractive methodology in modern organic synthesis. ${ }^{6}$ This combination allows for rapid production of molecular complexity and diversity from simple and readily accessible

*e-mail: ckleber@unb.br bioactive molecules. Recently, literature has provided many examples of microwave-promoted multicomponent reaction protocols, for example, Ugi, Biginelli and Hantzsch reactions. ${ }^{6}$ Nevertheless, to the best of our knowledge, the Passerini three-component reaction had not yet been explored. This reaction, ${ }^{7}$ described in 1921 , is a multicomponent reaction which provides $\alpha$-acyloxy carboxyamides by combining three building blocks in one step: a carboxylic acid, an oxo-component (aldehyde or ketone) and an isonitrile. ${ }^{8}$

In continuation to our research on MCRs, ${ }^{9}$ we herein report the results of a systematic study of unprecedented microwave-assisted Passerini reactions under solvent-free conditions (Scheme 1).

\section{Experimental}

All reactions were performed on a CEM Co., Discover microwave reactor using sealed vessels, dynamic program, at $60{ }^{\circ} \mathrm{C}$ or $120{ }^{\circ} \mathrm{C}$ (temperature detection by internal fiber optic probe), with stirring, simultaneous cooling and at a fixed power $(40 \mathrm{~W})$. Melting points were recorded on a Thomas Hoover Capillary melting point apparatus and are uncorrected. IR spectra were recorded on a Bomem MB-100 


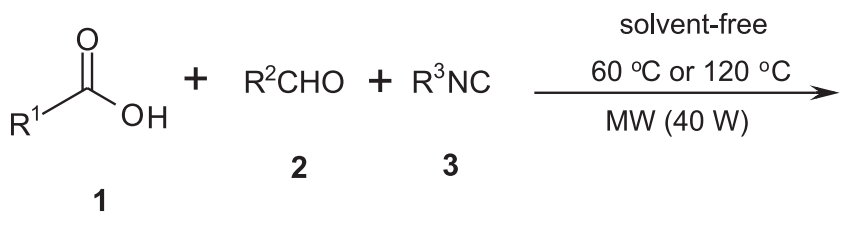<smiles>[R]NC(=O)C([R])OC([R])=O</smiles>

Scheme 1. MW-assisted Passerini reactions under solvent-free conditions

FTIR. ${ }^{1} \mathrm{H}$ and ${ }^{13} \mathrm{C}$ NMR spectra were recorded on a Varian Mercury Plus 300 spectrometer, operating at $300 \mathrm{MHz}$ for ${ }^{1} \mathrm{H}$ NMR and $75 \mathrm{MHz}$ for ${ }^{13} \mathrm{C}$ NMR. Chemical shifts $(\delta$ ppm) in $\mathrm{CDCl}_{3}$ were reported downfield from TMS $(=0)$ for ${ }^{1} \mathrm{H}$ NMR. For ${ }^{13} \mathrm{C}$ NMR, chemical shifts were reported in the scale relative to $\mathrm{CDCl}_{3}(77.00 \mathrm{ppm})$ as an internal reference. Column chromatography was performed on silica gel (Acros Organic 0.035-0.070 mm). High resolution mass spectra (electrospray ionization) were obtained using a Micro TOF Ic-Bruker Daltonics instrument. All compounds were analyzed by ${ }^{1} \mathrm{H}$ NMR, ${ }^{13} \mathrm{C}$ NMR, IR, melting points (for solid products) and high resolution mass spectra giving data consistent with those proposed.

\section{General procedure for the Passerini reaction}

A sealed $10 \mathrm{~mL}$ glass tube containing the carboxylic acid (1 equiv.), the aldehyde (1 equiv.) and the isonitrile ( 1 equiv.) was introduced in the cavity of a microwave reactor (CEM Co., Discover). The flask was irradiated $(40 \mathrm{~W})$ while stirring for the time and temperature specified in Table 1. Purification by column chromatography on silica gel eluted with 4:6 (4a-g) or 2:8 (4h-j) ethyl acetate-hexane gave the pure products.

Compound 4a: Prepared following the general procedure using Cbz-glycine $(0.042 \mathrm{~g}, 0.20 \mathrm{mmol})$, methyl isocyanoacetate $(0.020 \mathrm{~g}, 0.20 \mathrm{mmol})$ and benzaldehyde $(0.021 \mathrm{~g}, 0.20 \mathrm{mmol})$. Compound $\mathbf{4 a}$ was purified by column chromatography on silica gel eluted with 4:6 ethyl acetate-hexane $(0.059 \mathrm{~g}, 71 \%)$; white solid; $\mathrm{mp} 117-118^{\circ} \mathrm{C}$; IR (film) $v_{\text {max }} / \mathrm{cm}^{-1} 3376,3294,1750,1681,1513,1205$; ${ }^{1} \mathrm{H} \mathrm{NMR}\left(300 \mathrm{MHz}, \mathrm{CDCl}_{3}\right) \delta$ 7.45-7.41 (m, 2H), 7.37-7.32 (m, 8H), 7.16 (br t, J 5.5 Hz, 1H), $6.17(\mathrm{~s}, 1 \mathrm{H}), 5.50$ (br t, $J 5.4 \mathrm{~Hz}, 1 \mathrm{H}), 5.14(\mathrm{~d}, J 16.0 \mathrm{~Hz}, 1 \mathrm{H}), 5.10(\mathrm{~d}, J 16.0 \mathrm{~Hz}$, $1 \mathrm{H}), 4.11-4.02(\mathrm{~m}, 3 \mathrm{H}), 3.94(\mathrm{dd}, J 5.4$ and $18.1 \mathrm{~Hz}, 1 \mathrm{H}), 3.71$ (s, 3H); $\left.{ }^{13} \mathrm{C} \mathrm{NMR} \mathrm{(75} \mathrm{MHz,} \mathrm{CDCl}_{3}\right) \delta 169.9,168.5,168.3$, $156.8,135.9,134.5,129.3,128.8,128.5,128.2,128.0,127.7$, 76.0, 67.3, 52.3, 43.0, 40.9. ESI-HRMS $[\mathrm{M}+\mathrm{Na}]^{+}$Found: 437.1301. Calc. for $\mathrm{C}_{21} \mathrm{H}_{22} \mathrm{~N}_{2} \mathrm{O}_{7} \mathrm{Na}$ : 437.1325.

Compound $\mathbf{4 b}$ : Prepared following the general procedure using Cbz-glycine $(0.042 \mathrm{~g}, 0.20 \mathrm{mmol})$, methyl isocyanoacetate $(0.020 \mathrm{~g}, 0.2 \mathrm{mmol})$ and isobutyraldehyde
(0.014 g, $0.20 \mathrm{mmol})$. Compound $\mathbf{4 b}$ was purified by column chromatography on silica gel eluted with 4:6 ethyl acetate-hexane $(0.064 \mathrm{~g}, 84 \%)$; white solid; $\mathrm{mp} 77-78^{\circ} \mathrm{C}$; IR (film) $v_{\text {max }} / \mathrm{cm}^{-1} 3325,3072,3041,2966,1748,1693$, $1657,1538,1248 ;{ }^{1} \mathrm{H}$ NMR $\left(300 \mathrm{MHz}, \mathrm{CDCl}_{3}\right) \delta 7.32$ (s, $5 \mathrm{H}), 7.08(\mathrm{br} \mathrm{t}, J 5.5 \mathrm{~Hz}, 1 \mathrm{H}), 5.13-5.11(\mathrm{~m}, 1 \mathrm{H}), 5.10(\mathrm{~s}$, 2H), 5.65 (brt $, J 5.7 \mathrm{~Hz}, 1 \mathrm{H}), 4.12-3.92(\mathrm{~m}, 3 \mathrm{H}), 3.87$ (dd, $J 5.5$ and $18.0 \mathrm{~Hz}, 1 \mathrm{H}), 3.70(\mathrm{~s}, 3 \mathrm{H}), 2.33-2.25(\mathrm{~m}, 1 \mathrm{H})$, $0.94(\mathrm{~d}, J 6.8 \mathrm{~Hz}, 3 \mathrm{H}) 0.93(\mathrm{~d}, J 6.8 \mathrm{~Hz}, 3 \mathrm{H}) ;{ }^{13} \mathrm{C} \mathrm{NMR}$ $\left(75 \mathrm{MHz}, \mathrm{CDCl}_{3}\right) \delta 170.0,169.5,169.0,157.1,135.9$, 128.5, 128.3, 128.0, 78.7, 67.3, 52.2, 43.0, 40.6, 30.4, 18.7, 16.4. ESI-HRMS [M+Na] ${ }^{+}$Found: 403.1479. Calc. for $\mathrm{C}_{18} \mathrm{H}_{24} \mathrm{~N}_{2} \mathrm{O}_{7} \mathrm{Na}$ : 403.1481 .

Compound $4 \boldsymbol{c}$ : Prepared following the general procedure using Cbz-glycine $(0.21 \mathrm{~g}, 1.00 \mathrm{mmol})$, methyl isocyanoacetate $(0.10 \mathrm{~g}, 1.00 \mathrm{mmol})$ and $p$-nitrobenzaldehyde $(0.15 \mathrm{~g}, 1.00 \mathrm{mmol})$. Compound $4 \mathbf{c}$ was purified by column chromatography on silica gel eluted with 4:6 ethyl acetate-hexane $(0.31 \mathrm{~g}, 68 \%)$; white solid; mp 143-144 ${ }^{\circ} \mathrm{C}$; IR (film) $v_{\max } / \mathrm{cm}^{-1} 3296$, 3098, 3078, 1753, 1701, 1696, 1532, 1233; ${ }^{1} \mathrm{H}$ NMR $\left(300 \mathrm{MHz}, \mathrm{CDCl}_{3}\right) \delta 8.14(\mathrm{~d}, J 8.7,2 \mathrm{H}) ; 7.60(\mathrm{~d}, J 8.7 \mathrm{~Hz}$, 2H), 7.45 (br t, J 5.5 Hz, 1H), 7.38-7.25 (m, 5H), 6.23 (s, 1H), 5.67 (br t, $J 6.1 \mathrm{~Hz}, 1 \mathrm{H}), 5.14(\mathrm{~d}, J 19.4 \mathrm{~Hz}, 1 \mathrm{H})$, $5.10(\mathrm{~d}, J 19.4 \mathrm{~Hz}, 1 \mathrm{H}), 4.08-4.01(\mathrm{~m}, 3 \mathrm{H}), 3.91(\mathrm{dd}$, $J 5.5$ and $18.0 \mathrm{~Hz}, 1 \mathrm{H}), 3.70(\mathrm{~s}, 3 \mathrm{H}) ;{ }^{13} \mathrm{C}$ NMR $(75 \mathrm{MHz}$, $\left.\mathrm{CDCl}_{3}\right) \delta 169.7,168.2,167.3,157.0,148.1,141.4$, 135.8, 128.6, 128.3, 128.0, 123.8, 74.7, 67.4, 52.4, 43.0, 40.9. ESI-HRMS $[\mathrm{M}+\mathrm{Na}]^{+}$Found: 482.1171. Calc. for $\mathrm{C}_{21} \mathrm{H}_{21} \mathrm{~N}_{3} \mathrm{O}_{9} \mathrm{Na}: 482.1176$.

Compound 4d: Prepared following the general procedure using Cbz-glycine $(0.21 \mathrm{~g}, 1.00 \mathrm{mmol})$, methyl isocyanoacetate $(0.10 \mathrm{~g}, 1.00 \mathrm{mmol})$ and $p$-chlorobenzaldehyde $(0.14 \mathrm{~g}, 1.00 \mathrm{mmol})$. Compound 4d was purified by column chromatography on silica gel eluted with 4:6 ethyl acetate-hexane $(0.27 \mathrm{~g}, 61 \%)$; white solid; mp 123-124 ${ }^{\circ} \mathrm{C}$; IR (film) $v_{\max } / \mathrm{cm}^{-1} 3296,3114$, 3088, 2956, 1743, 1686, 1542, 1516, 1233; ${ }^{1} \mathrm{H}$ NMR $\left(300 \mathrm{MHz}, \mathrm{CDCl}_{3}\right) \delta$ 7.39-7.30 (m, 9H), 7.20 (br t, $J 5.4 \mathrm{~Hz}, 1 \mathrm{H}), 6.14(\mathrm{~s}, 1 \mathrm{H}), 5.46($ br t, $J 5.8 \mathrm{~Hz}, 1 \mathrm{H})$, $5.15(\mathrm{~d}, J 17.2 \mathrm{~Hz}, 1 \mathrm{H}), 5.11(\mathrm{~d}, J 17.2 \mathrm{~Hz}, 1 \mathrm{H}), 4.13-$ $4.04(\mathrm{~m}, 3 \mathrm{H}), 3.94(\mathrm{dd}, J 5.1$ and $18.0 \mathrm{~Hz}, 1 \mathrm{H}), 3.73$ (s, 
$3 \mathrm{H}) ;{ }^{13} \mathrm{C} \mathrm{NMR}\left(75 \mathrm{MHz}, \mathrm{CDCl}_{3}\right) \delta 169.9,168.6,168.2$ $157.0,136.0,135.3,133.1,129.1,129.0,128.6,128.4$, 128.1, 75.2, 67.3, 52.4, 43.0, 40.9. ESI-HRMS [M+Na $]^{+}$ Found: 471.0937. Calc. for $\mathrm{C}_{21} \mathrm{H}_{21} \mathrm{ClN}_{2} \mathrm{O}_{7} \mathrm{Na}$ : 471.0935 .

Compound 4e: Prepared following the general procedure using Cbz-glycine $(0.084 \mathrm{~g}, 0.40 \mathrm{mmol})$, methyl isocyanoacetate $(0.040 \mathrm{~g}, 0.40 \mathrm{mmol})$ and $m$-methoxybenzaldehyde $(0.054 \mathrm{~g}, 0.40 \mathrm{mmol})$. Compound $\mathbf{4 e}$ was purified by column chromatography on silica gel eluted with 4:6 ethyl acetate-hexane $(0.15 \mathrm{~g}$, $82 \%$ ); white solid; mp $88^{\circ} \mathrm{C}$; IR (film) $\mathrm{v}_{\max } / \mathrm{cm}^{-1} 3372$, 2938, 2928, 1753, 1741, 1712, 1677, 1515, 1206; ${ }^{1} \mathrm{H}$ NMR $\left(300 \mathrm{MHz} \mathrm{CDCl}_{3}\right) \delta 7.40-7.22(\mathrm{~m}, 6 \mathrm{H}), 7.20(\mathrm{t}, J 5.7 \mathrm{~Hz}$, $1 \mathrm{H}), 7.10-6.98(\mathrm{~m}, 2 \mathrm{H}), 6.88$ (ddd, $J 8.3,2.7$ and $1.1 \mathrm{~Hz}$, $1 \mathrm{H}), 6.13$ (s, 1H), 5.60 (br t, J 6.0 Hz, 1H), 5.15-5.07 (m, 2H), 4.10-4.02 (m, 3H), $3.92(\mathrm{dd}, J 5.3$ and $18.0 \mathrm{~Hz}, 1 \mathrm{H})$, 3.78 (s, 3H), $3.70(\mathrm{~s}, 3 \mathrm{H}) ;{ }^{13} \mathrm{C}$ NMR $\left(75 \mathrm{MHz}, \mathrm{CDCl}_{3}\right)$ $\delta 169.8,168.5,168.3,159.7,156.8,135.9,129.8,128.5$, 128.2, 128.0, 119.8, 114.9, 113.1, 75.8, 67.2, 55.2, 52.3, 42.9, 40.8. EI-HRMS [M+Na] ${ }^{+}$Found: 467.1428. Calc. for $\mathrm{C}_{22} \mathrm{H}_{24} \mathrm{~N}_{2} \mathrm{O}_{8} \mathrm{Na}$ : 467.1430 .

Compound 4f: Prepared following the general procedure using Cbz-glycine $(0.084 \mathrm{~g}, 0.40 \mathrm{mmol})$, methyl isocyanoacetate $(0.040 \mathrm{~g}, 0.40 \mathrm{mmol})$ and $o$-methoxybenzaldehyde $(0.054 \mathrm{~g}, 0.40 \mathrm{mmol})$. Compound 4f was purified by column chromatography on silica gel eluted with 4:6 ethyl acetate-hexane $(0.140 \mathrm{~g}, 79 \%)$; colorless oil; IR (film) $v_{\max } / \mathrm{cm}^{-1} 3345,3072,3031,2954$, 1748, 1676, 1537, 1214; ${ }^{1} \mathrm{H}$ NMR (300 MHz, $\mathrm{CDCl}_{3}$ ) $\delta$ 7.40-7.37 (m, 1H), 7.40-7.30 (m, 6H), 7.04 (br t, $J 4.6 \mathrm{~Hz}, 1 \mathrm{H}), 6.99$ (dd, J 1.0 and $7.5 \mathrm{~Hz}, 1 \mathrm{H}), 6.94$ (d, $J 8.3 \mathrm{~Hz}, 1 \mathrm{H}), 6.53(\mathrm{~s}, 1 \mathrm{H}), 5.41(\mathrm{t}, J 5.7 \mathrm{~Hz}, 1 \mathrm{H}), 5.12$ (s, 2H), 4.14-4.08 (m, 3H), 4.01 (dd, J 5.3 and $19.6 \mathrm{~Hz}, 1 \mathrm{H})$, 3.92 (s, 3H), 3.72 (s, 3H); ${ }^{13} \mathrm{C} \mathrm{NMR} \mathrm{(75} \mathrm{MHz,} \mathrm{CDCl}_{3}$ ) $\delta 169.9,169.0,161.0,156.5,136.1,130.4,128.5,128.3$, 128.2, 128.0, 122.9, 121.1, 110.9, 70.5, 67.1, 55.8, 52.4, 42.9, 41.1. ESI-HRMS [M+Na $]^{+}$Found: 467.1428. Calc. for $\mathrm{C}_{22} \mathrm{H}_{24} \mathrm{~N}_{2} \mathrm{O}_{8} \mathrm{Na}$ : 467.1430 .

Compound $4 \mathrm{~g}$ : Prepared following the general procedure using Cbz-glycine $(0.050 \mathrm{~g}, 0.24 \mathrm{mmol})$, methyl isocyanoacetate $(0.024 \mathrm{~g}, 0.24 \mathrm{mmol})$ and $o$-methoxybenzaldehyde $(0.034 \mathrm{~g}, 0.24 \mathrm{mmol})$. Compound $\mathbf{4 g}$ was purified by column chromatography on silica gel eluted with 4:6 ethyl acetate-hexane $(0.074 \mathrm{~g}, 69 \%)$; colorless oil; IR (film) $v_{\max } / \mathrm{cm}^{-1} 3325,3072,2949,1753$, 1685, 1532, 1217, 1174; ${ }^{1} \mathrm{H}$ NMR $\left(300 \mathrm{MHz}, \mathrm{CDCl}_{3}\right) \delta$ 7.52-7.49 (m, 1H), 7.40-7.37 (m, 1H), 7.32-7.23 (m, 8H), 6.57 (s, 1H), 5.60 (t, J 5.7 Hz, 1H), 5.12 (d, J 14.7 Hz, 1H), $5.08(\mathrm{~d}, J 14.7 \mathrm{~Hz}, 1 \mathrm{H}), 4.10(\mathrm{dd}, J 5.7$ and $18.0 \mathrm{~Hz}, 1 \mathrm{H})$, 4.05-3.98 (m, 2H), $3.92(\mathrm{dd}, J 5.2$ and $17.9 \mathrm{~Hz}, 1 \mathrm{H}), 3.71$ $(\mathrm{s}, 3 \mathrm{H}) ;{ }^{13} \mathrm{C} \mathrm{NMR}\left(75 \mathrm{MHz}, \mathrm{CDCl}_{3}\right) \delta 169.7,168.6,167.7$, $156.8,135.9,133.9,132.5,130.5,129.8,128.4,128.2$, 127.9, 127.3, 72.8, 67.2, 52.3, 42.8, 40.9. ESI-HRMS $[\mathrm{M}+\mathrm{Na}]^{+}$Found: 471.0930. Calc. for $\mathrm{C}_{21} \mathrm{H}_{21} \mathrm{ClN}_{2} \mathrm{O}_{7} \mathrm{Na}$ : 471.0935.

Compound $\mathbf{4 h}$ : Prepared following the general procedure using benzoic acid $(0.030 \mathrm{~g}, 0.24 \mathrm{mmol})$, tertbutyl isocyanide $(0.020 \mathrm{~g}, 0.24 \mathrm{mmol})$ and piperonal (0.036 g, $0.24 \mathrm{mmol}$ ). Compound $4 \mathrm{~h}$ was purified by column chromatography on silica gel eluted with 2:8 ethyl acetate-hexane $(0.060 \mathrm{~g}, 71 \%)$; white solid; mp 131-132 ${ }^{\circ} \mathrm{C}$; IR (film) $v_{\max } / \mathrm{cm}^{-1} 3303,3072,2974,2928$, 1718, 1656, 1552, 1249; ${ }^{1} \mathrm{H}$ NMR (300 MHz, $\mathrm{CDCl}_{3}$ ) $\delta$ 8.09-8.06 (m, 2H), 7.60-7.58 (m, 1H), $7.50(\mathrm{t}, J 8.4$ $\mathrm{Hz}, 1 \mathrm{H}), 7.02-6.98$ (m, 2H), 6.81 (d, J $8.4 \mathrm{~Hz}, 1 \mathrm{H}), 6.13$ (s, 1H), 6.02 (br s, 1H), 5.97 (s, 2H), 1.38 (s, 9H); ${ }^{13} \mathrm{C}$ NMR $\left(75 \mathrm{MHz}, \mathrm{CDCl}_{3}\right) \delta 167.3,164.8,147.9,133.6$, 129.7, 128.6, 121.7, 108.4, 107.8, 101.3, 75.8, 51.6, 28.6. ESI-HRMS $[\mathrm{M}+\mathrm{Na}]^{+}$Found: 378.1316 . Calc. for $\mathrm{C}_{20} \mathrm{H}_{21} \mathrm{NO}_{5} \mathrm{Na}$ : 378.1317 .

Compound $4 \mathbf{i}$ : Prepared following the general procedure using benzoic acid $(0.029 \mathrm{~g}, 0.24 \mathrm{mmol})$, tert-butyl isocyanide $(0.020 \mathrm{~g}, 0.24 \mathrm{mmol})$ and p-chlorobenzaldehyde $(0.034 \mathrm{~g}, 0.24 \mathrm{mmol})$. Compound 4i was purified by column chromatography on silica gel eluted with 2:8 ethyl acetate-hexane $(0.056 \mathrm{~g}, 68 \%)$, white solid; mp $185-186{ }^{\circ} \mathrm{C}$; IR (film) $v_{\max } / \mathrm{cm}^{-1} 3284$, 3088, 2973, 1727, 1600, 1492, 1260; ${ }^{1} \mathrm{H}$ NMR (300 MHz, $\left.\mathrm{CDCl}_{3}\right) \delta 8.08(\mathrm{dd}, J 8.3$ and $1.2 \mathrm{~Hz}, 2 \mathrm{H}), 7.65-7.59(\mathrm{~m}$, $1 \mathrm{H}), 7.51-7.46(\mathrm{~m}, 4 \mathrm{H}), 7.38-7.34(\mathrm{~m}, 2 \mathrm{H}), 6.19(\mathrm{~s}, 1 \mathrm{H})$, 6.10 (br s, 1H), 1.37 (s, 9H); ${ }^{13} \mathrm{C} \mathrm{NMR}\left(75 \mathrm{MHz}, \mathrm{CDCl}_{3}\right)$ $\delta$ 166.9, 164.7, 133.7, 129.7, 128.9, 128.7, 75.2, 51.6, 28.6. ESI-HRMS $[\mathrm{M}+\mathrm{Na}]^{+}$Found: 368.1034 . Calc. for $\mathrm{C}_{19} \mathrm{H}_{20} \mathrm{ClNO}_{3} \mathrm{Na}$ : 368.1029 .

Compound 4j: Prepared following the general procedure using benzoic acid $(0.061 \mathrm{~g}, 0.50 \mathrm{mmol})$, tert-butyl isocyanide $(0.041 \mathrm{~g}, 0.50 \mathrm{mmol})$ and $m$-methoxybenzaldehyde $(0.070 \mathrm{~g}, 0.50 \mathrm{mmol})$. Compound $\mathbf{4 j}$ was purified by column chromatography on silica gel eluted with $2: 8$ ethyl acetate-hexane $(0.123 \mathrm{~g}, 72 \%)$; white solid; mp 118-119 ${ }^{\circ} \mathrm{C}$; IR (film) $v_{\max } / \mathrm{cm}^{-1} 3299,3078,2975$, 1722, 1660, 1552, 1253; ${ }^{1} \mathrm{H}$ NMR $\left(300 \mathrm{MHz}, \mathrm{CDCl}_{3}\right) \delta 8.09$ (dd, $J 8.5$ and $1.5 \mathrm{~Hz}, 2 \mathrm{H}), 7.62-7.55(\mathrm{~m}, 1 \mathrm{H}), 7.45(\mathrm{t}, J 7.6$ $\mathrm{Hz}, 2 \mathrm{H}), 7.30$ (t, J 7.9 Hz, 1H), 7.13-7.08 (m, 2H), 6.89 (ddd, $J$ 8.2, 2.3 and $0.9 \mathrm{~Hz}, 1 \mathrm{H}), 6.20$ (s, 1H), 6.10 (br s, 1H), $3.79(\mathrm{~s}, 3 \mathrm{H}), 1.35(\mathrm{~s}, 9 \mathrm{H}) ;{ }^{13} \mathrm{C} \mathrm{NMR}\left(75 \mathrm{MHz}, \mathrm{CDCl}_{3}\right)$ 
Table 1. Microwave-assisted Passerini reactions

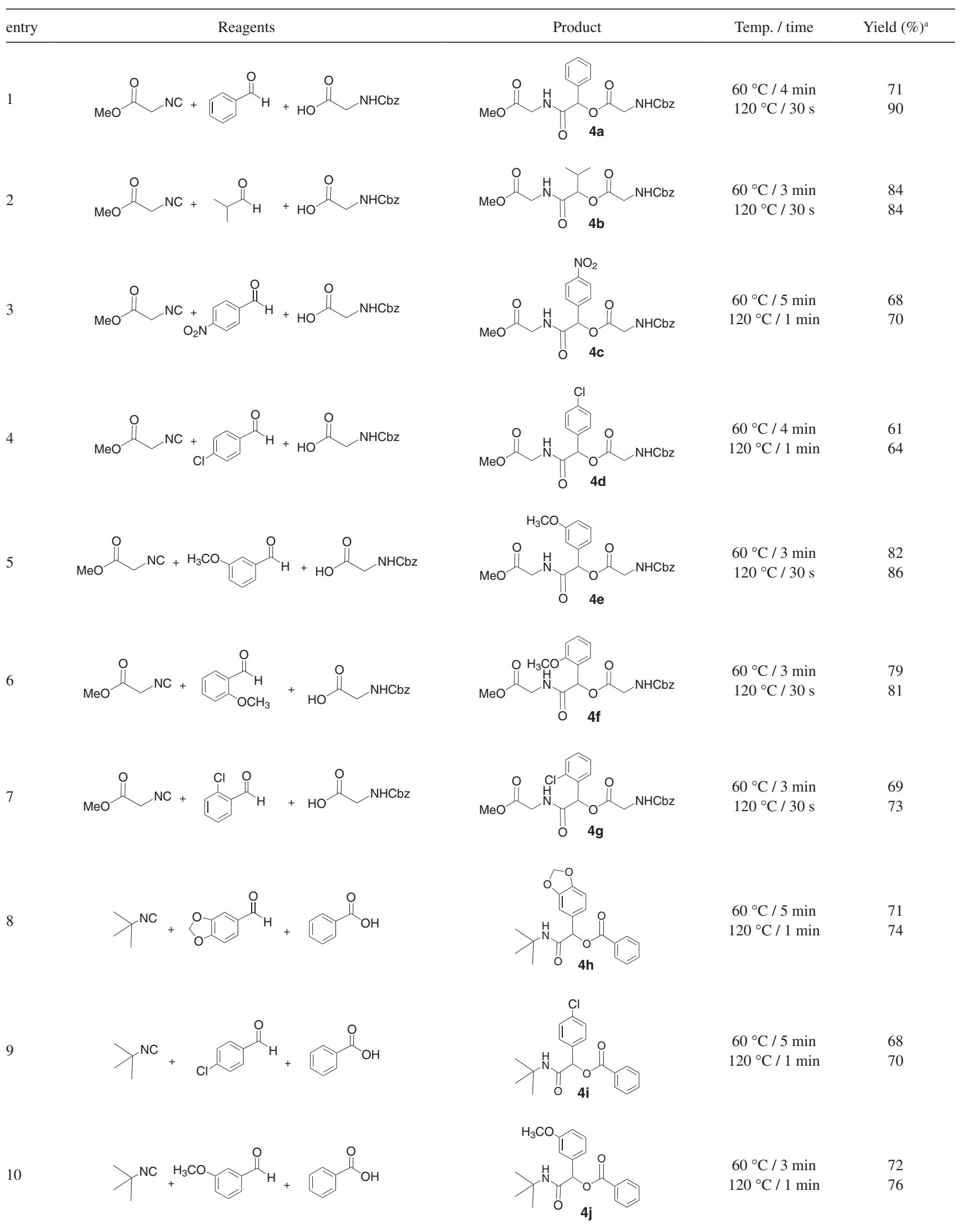

${ }^{a}$ Isolated yield of the chromatographically pure products. 
$\delta 167.1,159.6,137.2,133.4,129.6,129.1,128.5,119.5$ 114.2, 113.0, 75.8, 55.1, 51.4, 28.5. ESI-HRMS [M+Na] ${ }^{+}$ Found: 364.1524. Calc. for $\mathrm{C}_{20} \mathrm{H}_{23} \mathrm{NO}_{4} \mathrm{Na}$ : 364.1525.

\section{Results and Discussion}

In the synthesis of $\alpha$-acyloxy carboxyamides, aliphatic, aromatic and heteroaromatic aldehydes were reacted with equivalent amounts of isonitriles (methyl isocyanoacetate and tert-butyl isocyanide) and carboxylic acids (benzoic acid and Cbz-glycine). The three components were subjected to MW irradiation for the time specified in Table 1. Aromatic aldehydes substituted with both electron withdrawing and electron donating groups could be used successfully. The temperature was initially set at $60^{\circ} \mathrm{C}(40 \mathrm{~W})$ and the reactions were completed within 3-5 min as monitored by TLC showing the disappearance of the starting materials. Due to the good results obtained with the initial potency of $40 \mathrm{~W}$, it was kept constant and used in all experiments. The yields of the purified products were generally very good and varied according to the substitution pattern of the aromatic aldehydes. Increasing the temperature to $120^{\circ} \mathrm{C}$, the yields were slightly better in all cases except for benzaldehyde (entry 1) in which the yield of the product was significantly improved. Reaction times in Table 1 correspond to the time at which the temperature was maintained at 60 or $120^{\circ} \mathrm{C}$. Furthermore, in all cases the increase of the temperature caused a decrease in the reaction time.

The results obtained in this study, especially in terms of reaction time $\left(1 \mathrm{~min}\right.$ or less at $\left.120^{\circ} \mathrm{C}\right)$, are remarkable as compared with our previous results on the Passerini reaction using ionic liquids (2-14 h) and PEG (0.5-6 h) as alternative solvents. ${ }^{9}$ Compared to usual organic solvents, such as $\mathrm{CH}_{2} \mathrm{Cl}_{2}$, the difference for similar reactions is even greater (completion usually above $18 \mathrm{~h}$ ). ${ }^{10}$ Water has been demonstrated to accelerate these reactions but only in a limited extent (completion in 3-3.5 h).$^{10}$ According to a recent report on Passerini reactions, the yields were usually better under solvent-free conditions compared to the same reactions using dichloromethane as solvent. ${ }^{11}$

For comparison, the reactions of entries 1 and 2 were also performed using acetonitrile as solvent at $60^{\circ} \mathrm{C}$ (oil bath) allowed formation of the products after $3 \mathrm{~h}$ in moderate yields (65 and 64\%, respectively) as compared to 90 and $84 \%$ for the MW-assisted, solvent-free method (Table 1). The choice for acetonitrile relies on the fact that the acid component Cbz-glycine is not soluble in solvents commonly used in Passerini reactions such as dichloromethane. These results prove the superiority of our methodology in effectively promoting Passerini reactions.
Spectral analysis of $\mathbf{4 a - j}$ supported the success of the MW-mediated triple one-pot condensation. The isolated products were characterized on the basis of their IR, ${ }^{1} \mathrm{H}$ and ${ }^{13} \mathrm{C}$ NMR spectroscopy and mass spectra.

The most important characteristic of the ${ }^{1} \mathrm{H}$ NMR spectra is the presence of a singlet around $\delta 6.00-6.50 \mathrm{ppm}$ relative to the hydrogen of the stereogenic center (except for $\mathbf{4 b}$ which gives a doublet at $\delta 5.20 \mathrm{ppm}$ ). The ${ }^{13} \mathrm{C}$ NMR spectra corroborated the analysis of the compounds, showing four peaks corresponding to the carbonyl groups $(\delta 155-170 \mathrm{ppm})$ when Cbz-glycine and methyl isocyanoacetate were used. Accordingly, when benzoic acid and tert-butylisocyanide were used two peaks corresponding to the carbonyl groups were observed at $\delta 165-175 \mathrm{ppm}$.

\section{Conclusions}

A simple and efficient method was achieved for the preparation of $\alpha$-acyloxy carboxyamides. Compounds 4a-g are versatile multifunctional intermediates that can be further functionalized at the NCbz-moiety. For instance, $\mathbf{4 a - g}$ can be easily hydrolyzed to the respective acid components which could be used in a subsequent Passerini reaction opening the possibility for the study of consecutive Passerini reactions. This new methodology is already being developed in our research group. The simplicity of the reaction conditions, its efficacy and the excellent results obtained using two different temperatures, under solvent-free conditions, constitute an attractive contribution among the existing methodologies.

\section{Supplementary Information}

Supplementary data are available free of charge at http://jbcs.sbq.org.br, as PDF file.

\section{Acknowledgments}

We thank the Instituto de Química, Universidade de Brasília, FINEP-CT INFRA No. 970/01, CAPES and CNPq for financial support.

\section{References}

1. Ramon, D. J.; Yus, M.; Angew. Chem., Int. Ed. 2005, 44, 1602; Ugi, I.; Pure Appl. Chem. 2001, 73, 187; Hulme, C.; Gore, V.; Curr. Med. Chem. 2003, 10, 51.

2. Trost, B. M.; Science, 1991, 254, 1471; Trost, B. M.; Angew. Chem., Int. Ed. Engl. 1995, 34, 259.

3. Lenardão, E. J.; Freitag, R. A.; Dabdoub, M. J.; Batista, A. C. F.; Silveira, C. C.; Quim. Nova 2003, 26, 123; Dupont, J.; Quim. Nova 2000, 23, 825 . 
4. Varma, R. S.; Pure Appl. Chem. 2001, 73, 193; Varma, R. S.; Indian J. Chem., Sec. B: Org. Chem. Incl. Med. Chem. 2006, 45, 2305.

5. Kappe, C. O.; Chem. Soc. Rev. 2008, 37, 1127; Kappe, C. O. Angew. Chem., Int. Ed. 2004, 43, 6250; Lidström, P.; Tierney, J.; Wathey, B.; Westman, J.; Tetrahedron 2001, 57, 9225; Jiang, B.; Shi, F.; Tu, S. J.; Curr. Org. Chem. 2010, 14, 357; Zhu, Y. G.; Zhai, C. W.; Hu, W. H.; Prog. Chem. 2010, 22, 1380.

6. For a review on microwave-mediated multicomponent reactions, see: Hügel, H. M.; Molecules 2009, 14, 4936.

7. Passerini, M.; Gazz. Chim. Ital. 1921, 5, 126.
8. For reviews, see: Dömling, A.; Ugi, I.; Angew. Chem., Int. Ed. 2000, 39, 3169; Zhu, J. P.; Eur. J. Org. Chem. 2003, 1133; Dömling, A.; Chem. Rev. 2006, 106, 17.

9. Andrade, C. K. Z.; Takada, S. C. S.; Suarez, P. A. Z.; Alves, M. B.; Synlett 2006, 10, 1539; Vercillo, O. E.; Andrade, C. K. Z.; Wessjohann, L. A.; Org. Lett. 2008, 10, 205.

10. Pirrung, M. C., Sarma, K. D.; J. Am. Chem. Soc. 2004, 126, 444; Pirrung, M. C., Sarma, K. D.; Tetrahedron 2005, 61, 11456.

11. Koszelewski, D., Szymanski, W., Krysiak, J., Ostaszewski, R.; Synth. Commun. 2008, 38, 1120.

Submitted: July 28, 2010

Published online: October 21, 2010 


\section{Supplementary Information}

\section{Microwave-Assisted Passerini Reactions under Solvent-Free Conditions}

Angélica de Fátima S. Barreto, Otilie E. Vercillo and Carlos Kleber Z. Andrade*

LaQMOS - Instituto de Química, Universidade de Brasília, CP 4478, 70910-970 Brasília-DF, Brazil

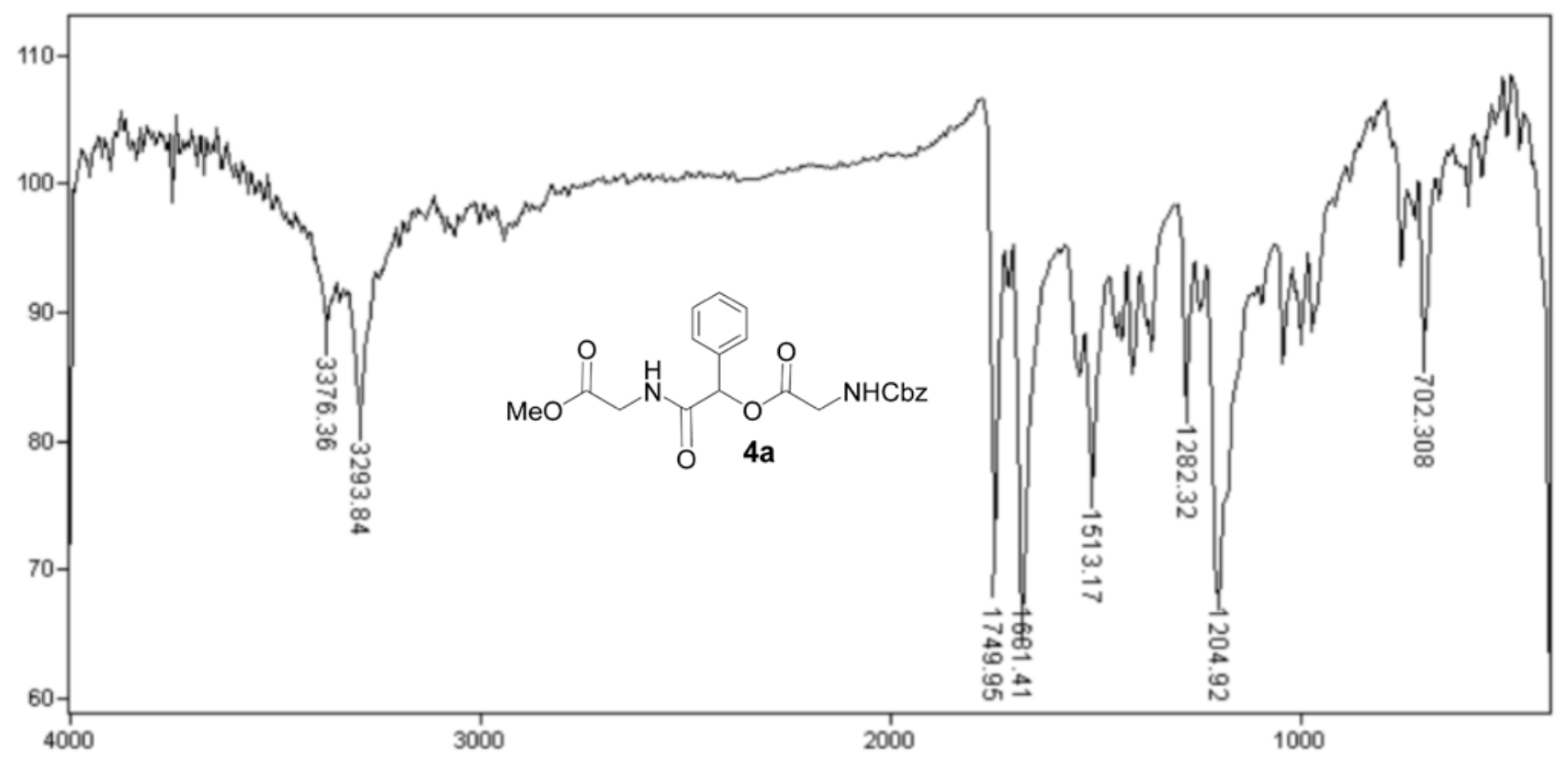

Figure S1. IR spectrum of $\mathbf{4 a .}$ 


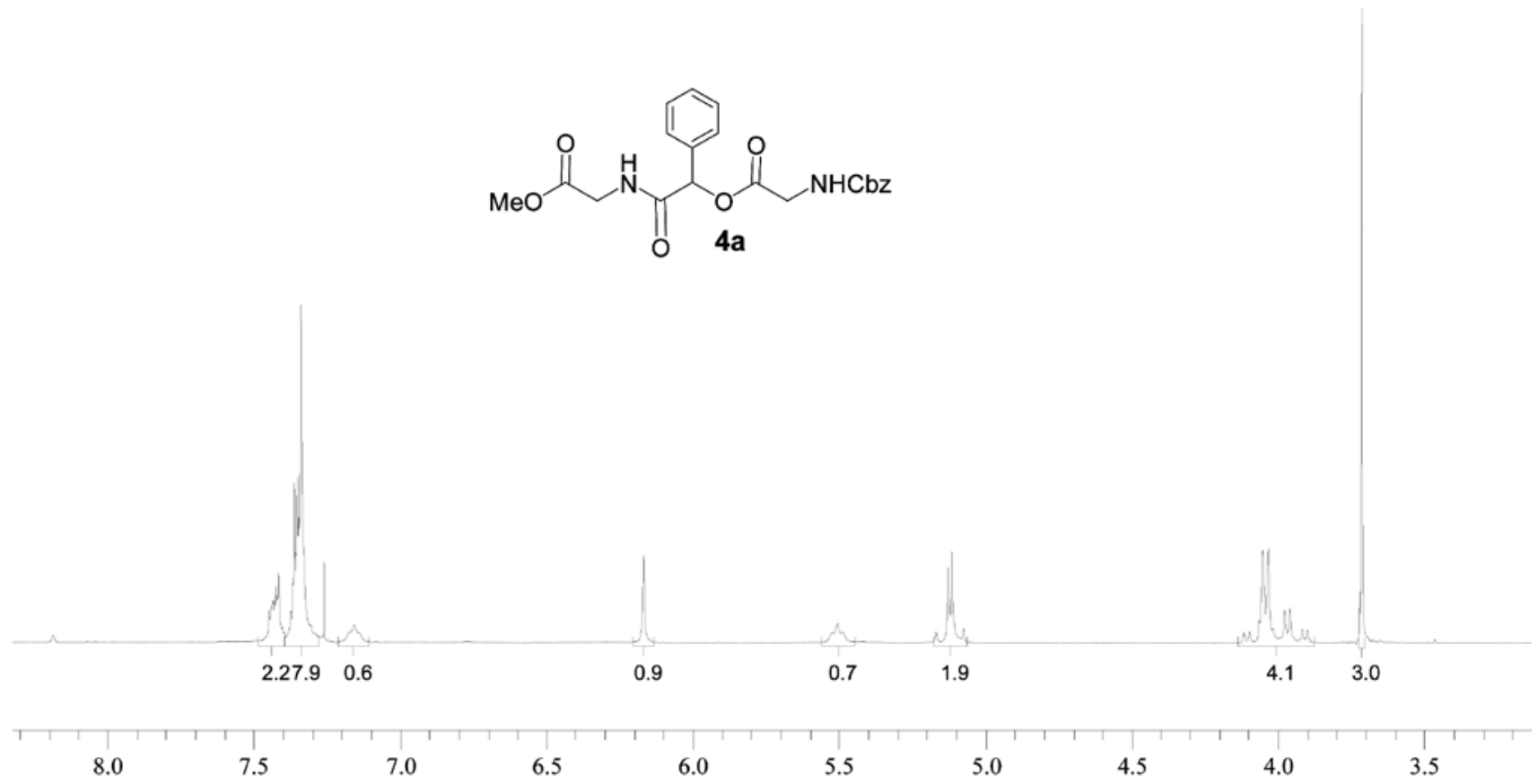

Figure S2. ${ }^{1} \mathrm{H}$ NMR $\left(\mathrm{CDCl}_{3}, 300 \mathrm{MHz}\right)$ of $\mathbf{4 a}$. Note: The number below each peak refers to the number of integration.

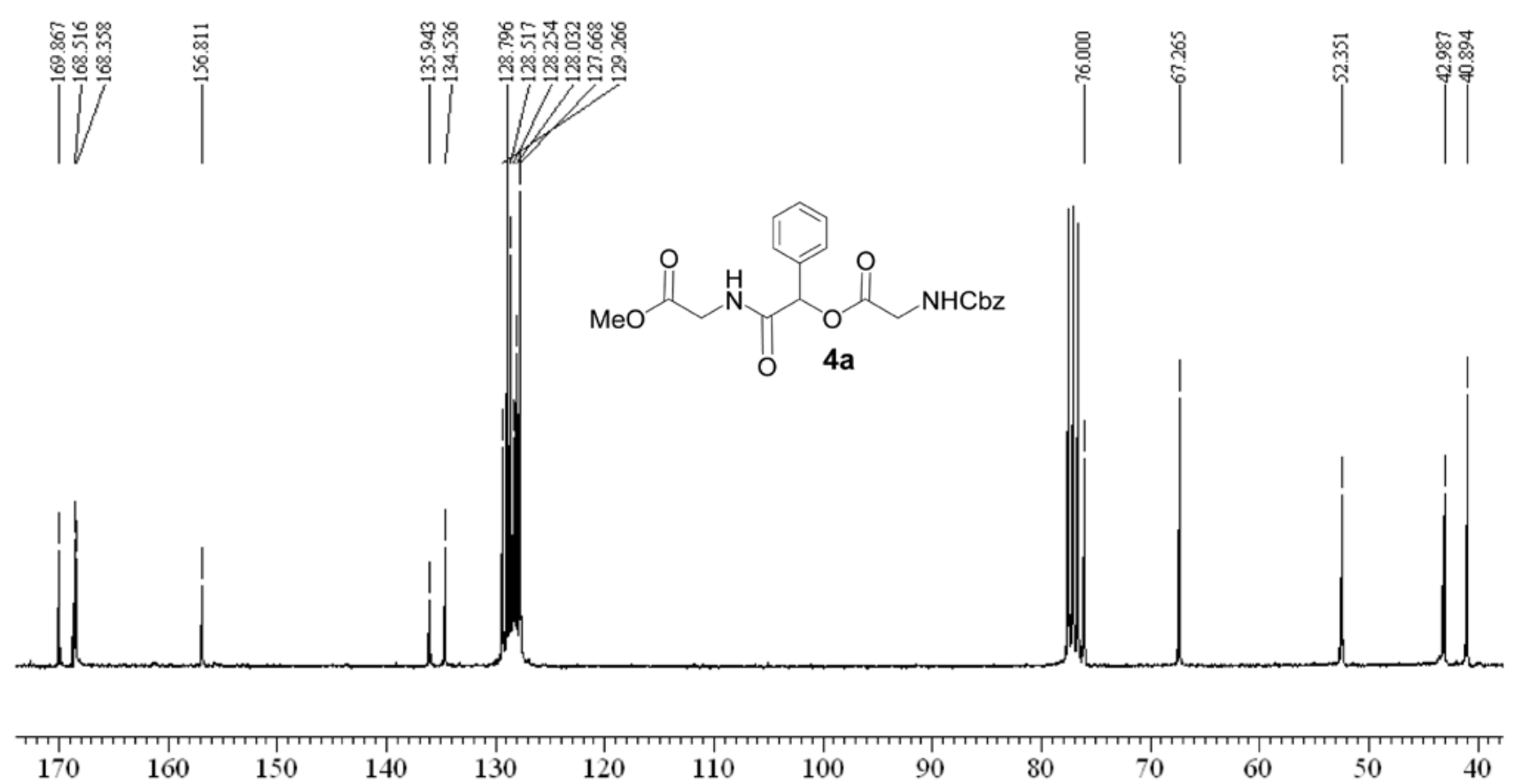

Figure S3. ${ }^{13} \mathrm{C}$ NMR $\left(\mathrm{CDCl}_{3}, 75 \mathrm{MHz}\right)$ of $\mathbf{4 a}$. 


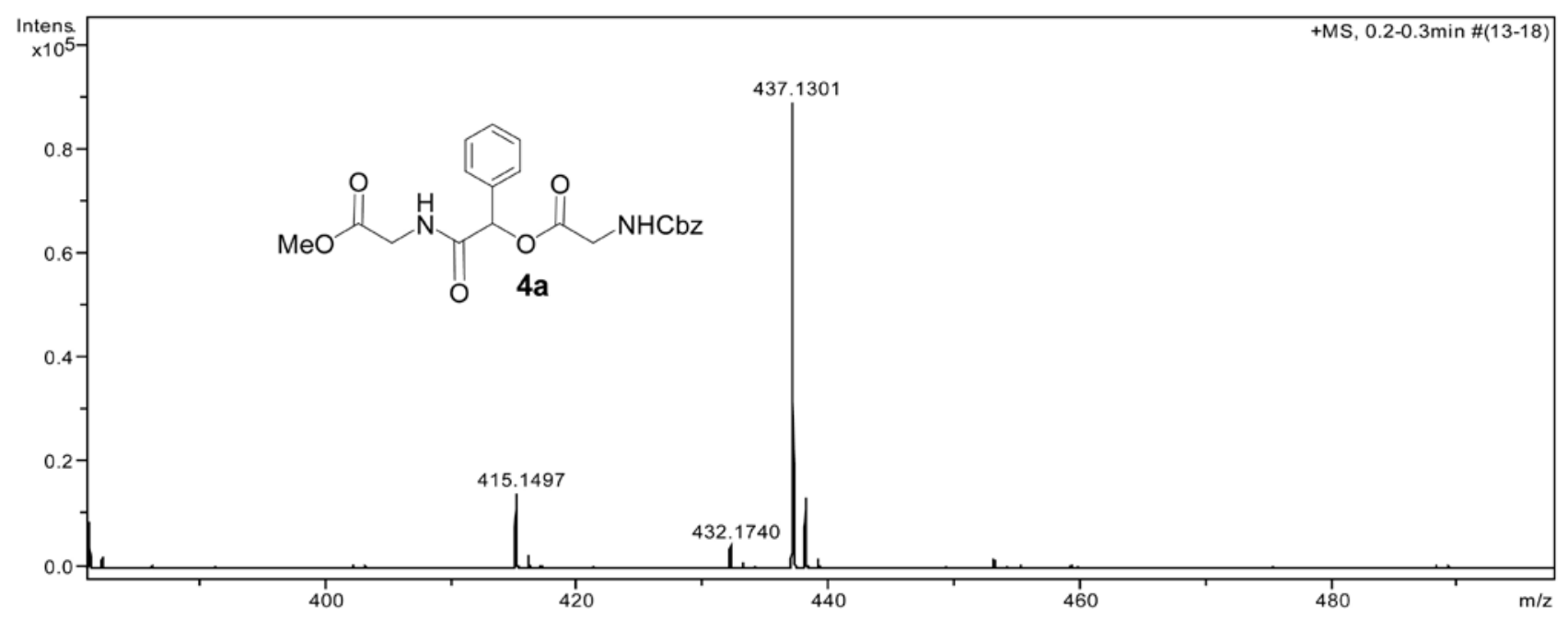

Figure S4. ESI-HRMS of $4 a$.

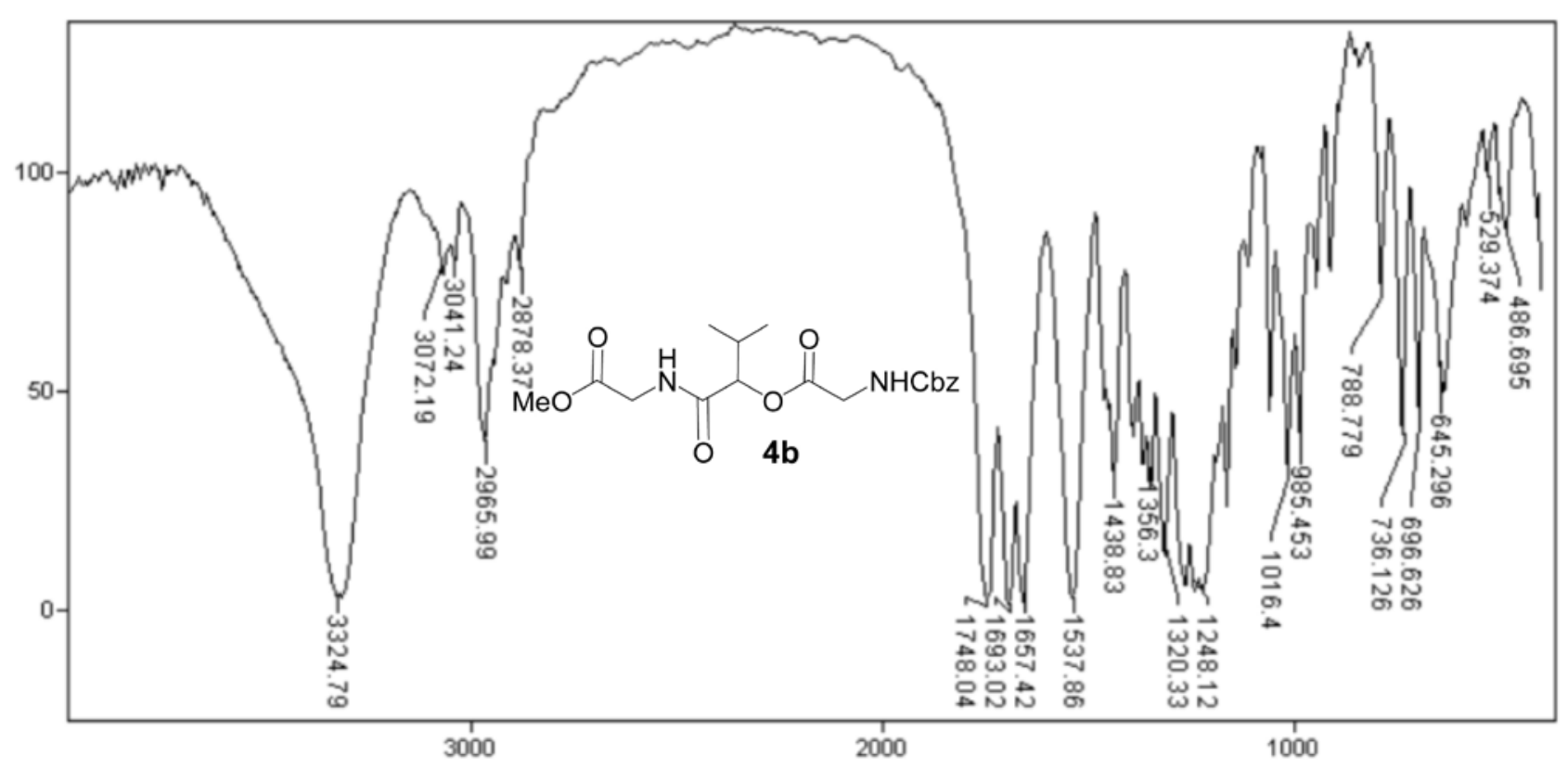

Figure S5. IR spectrum of $\mathbf{4 b}$. 


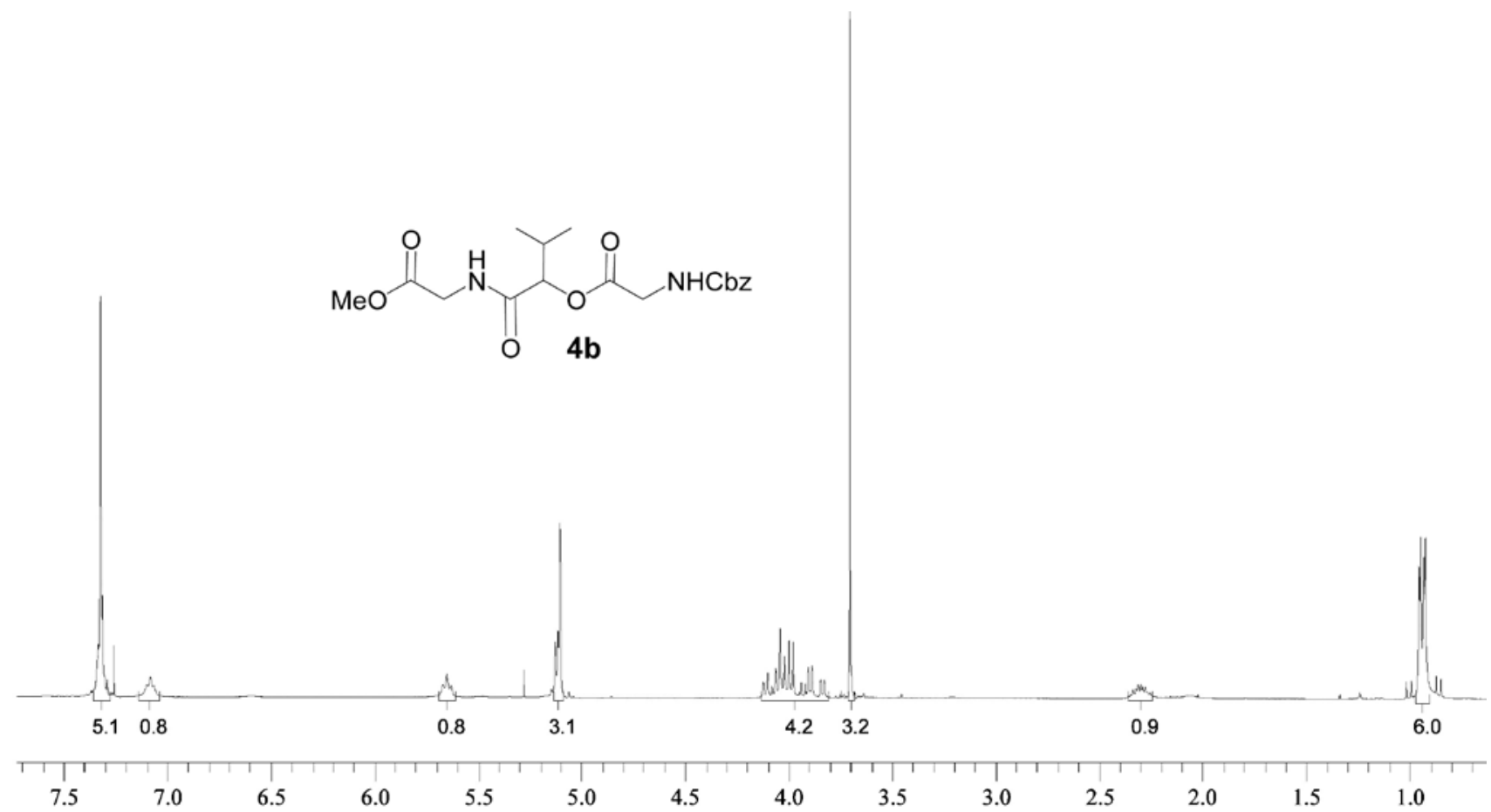

Figure S6. ${ }^{1} \mathrm{H} \mathrm{NMR}\left(\mathrm{CDCl}_{3}, 300 \mathrm{MHz}\right)$ of $\mathbf{4 b}$. Note: The number below each peak refers to the number of integration.

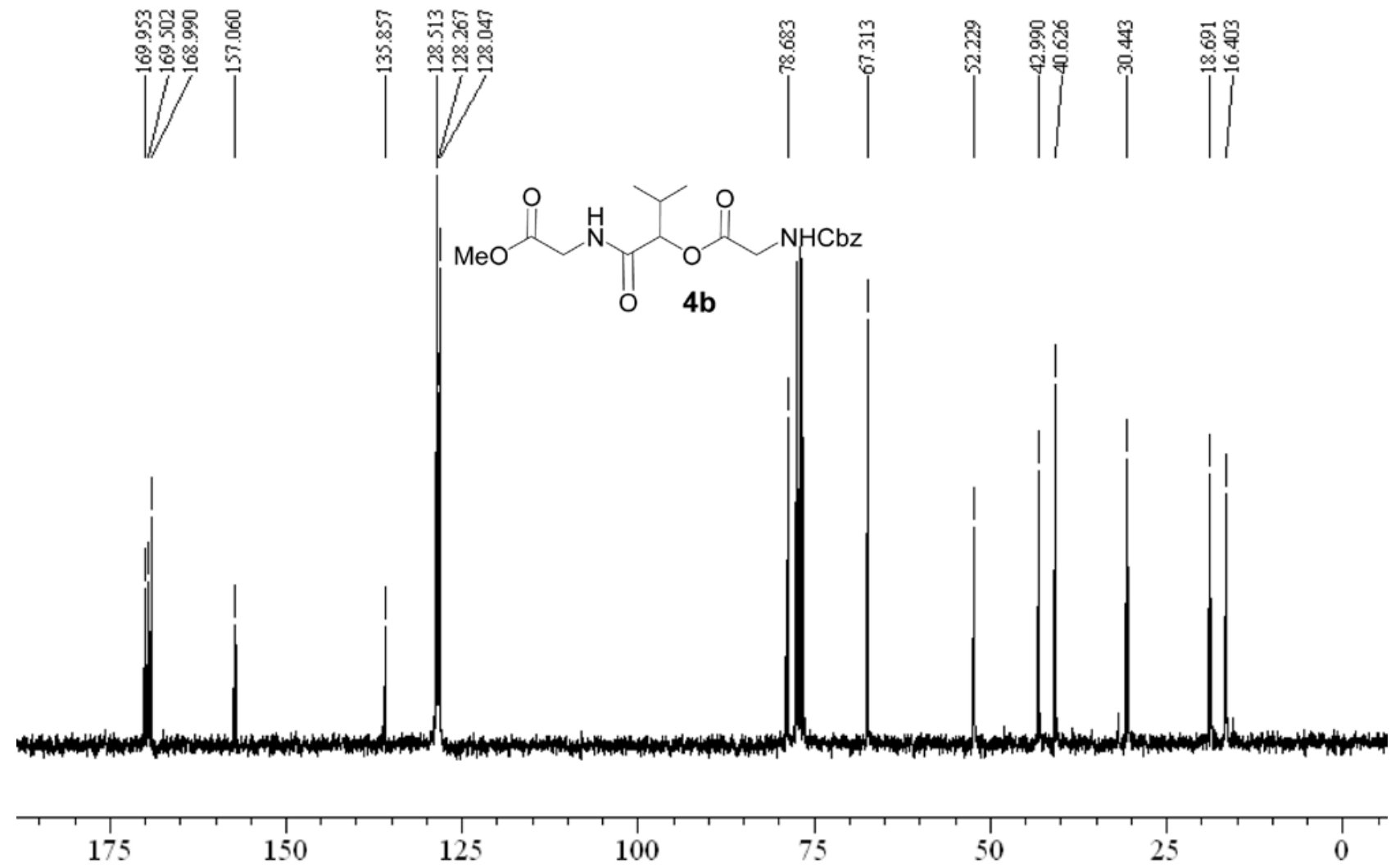

Figure S7. ${ }^{13} \mathrm{C} \mathrm{NMR}\left(\mathrm{CDCl}_{3}, 75 \mathrm{MHz}\right)$ of $\mathbf{4 b}$. 


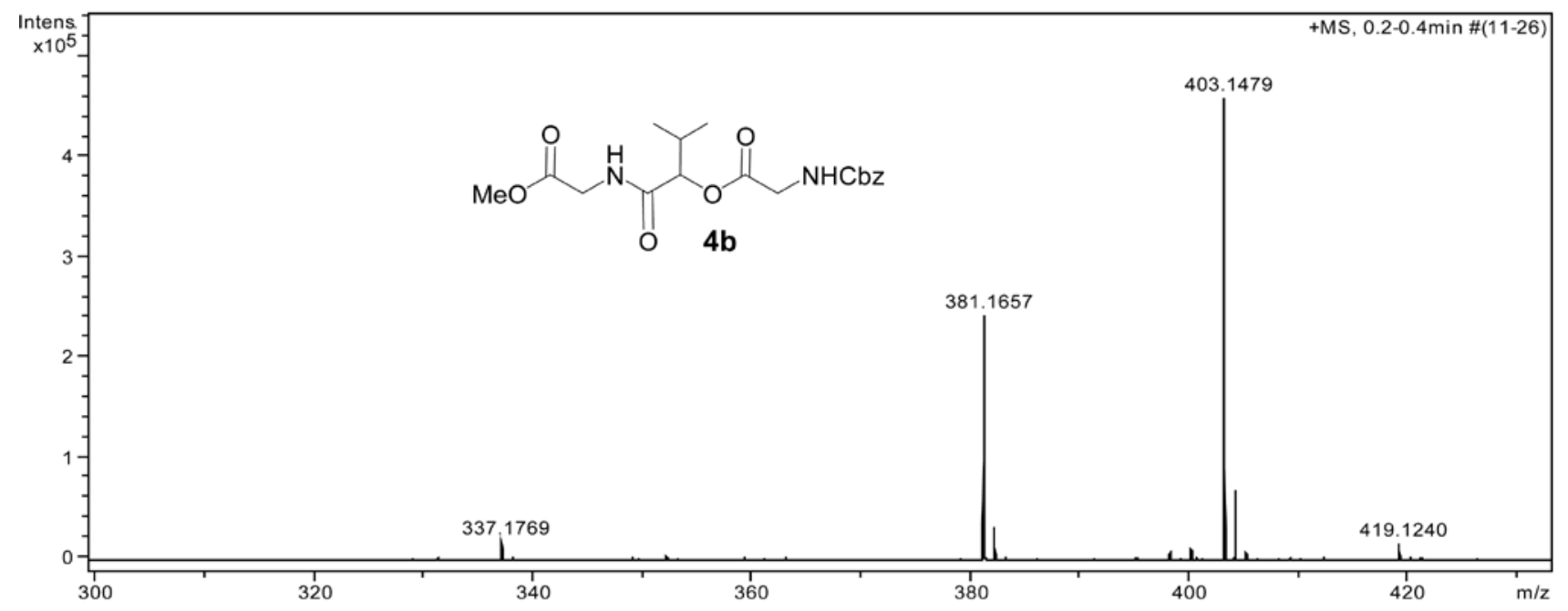

Figure S8. ESI-HRMS of $\mathbf{4 b}$.

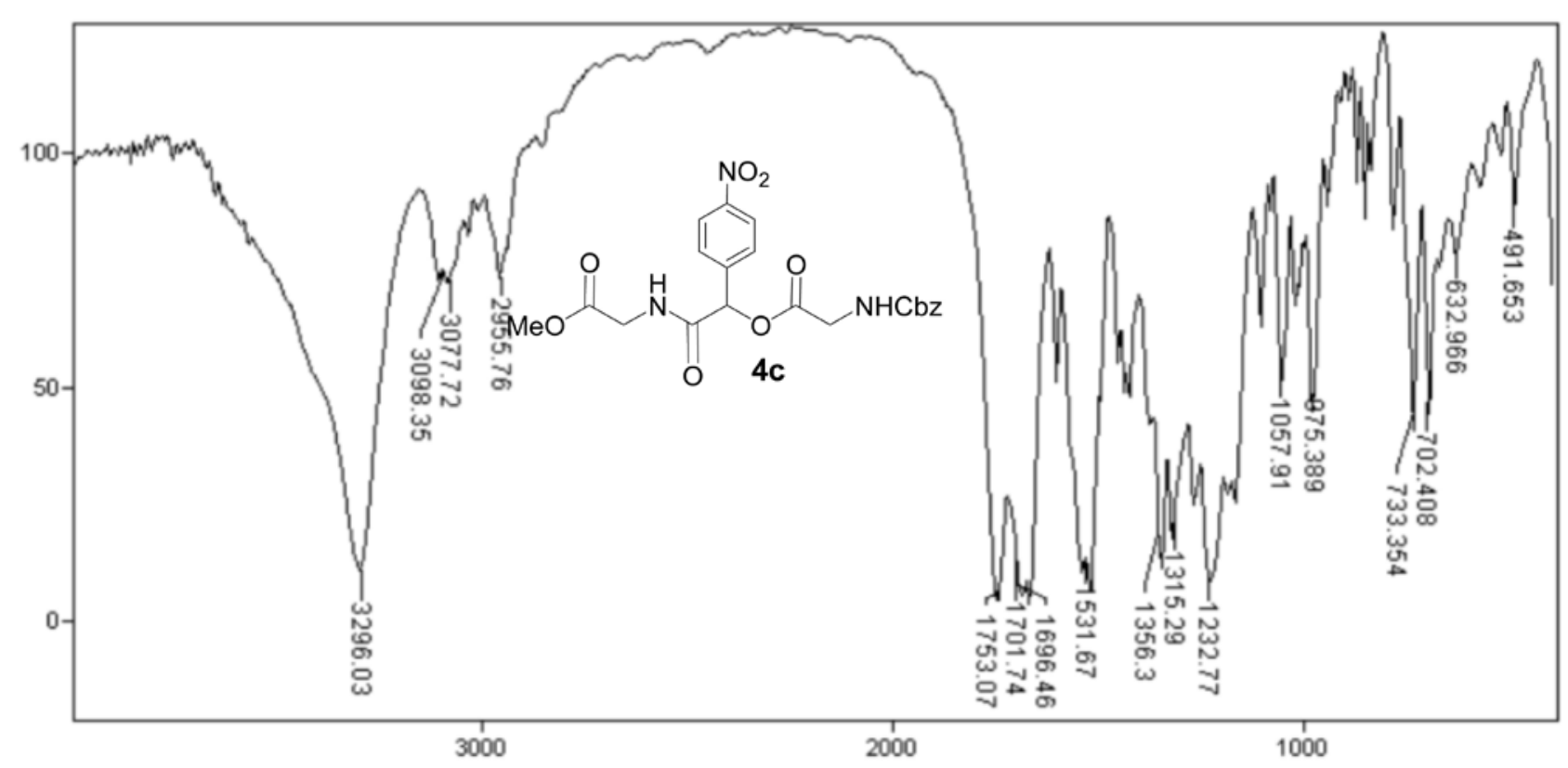

Figure S9. IR spectrum of $\mathbf{4 c}$. 


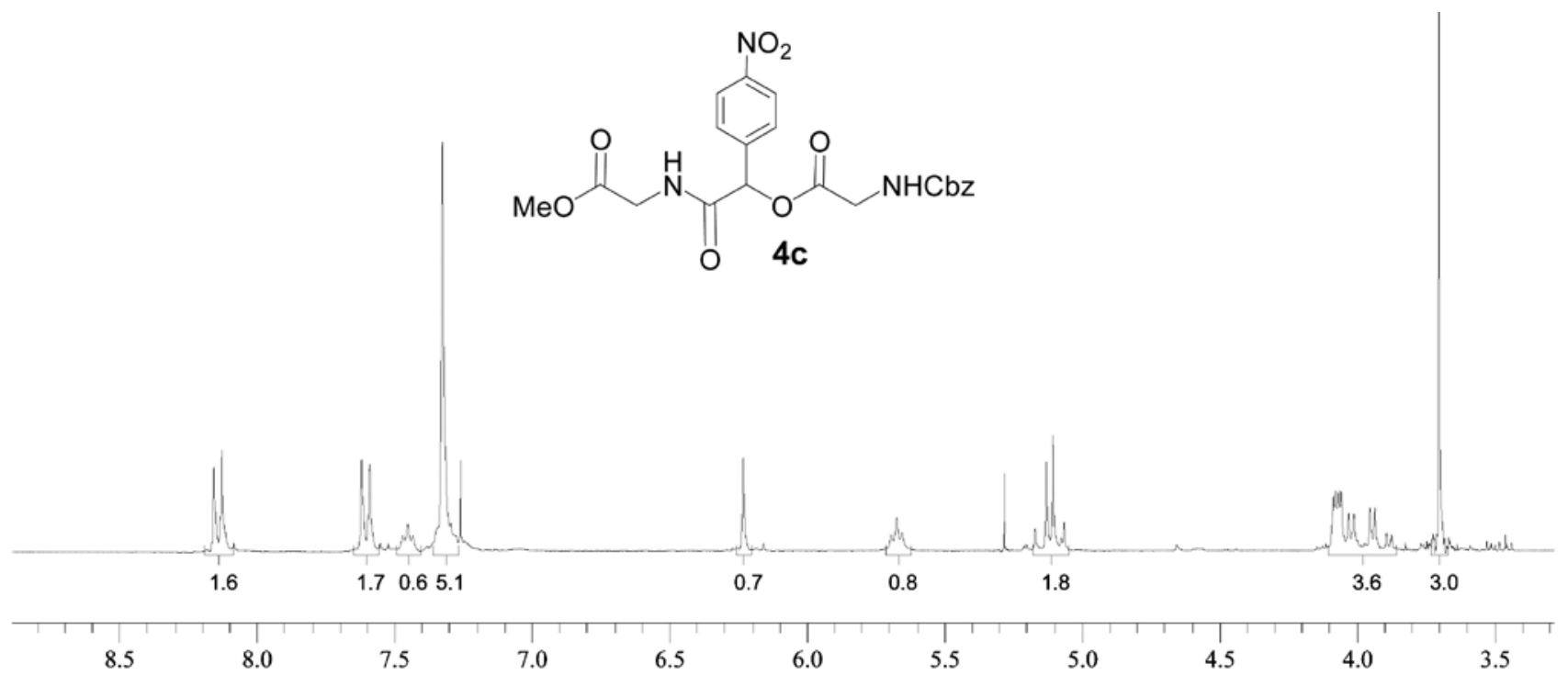

Figure S10. ${ }^{1} \mathrm{H}$ NMR $\left(\mathrm{CDCl}_{3}, 300 \mathrm{MHz}\right)$ of $\mathbf{4 c}$. Note: The number below each peak refers to the number of integration.
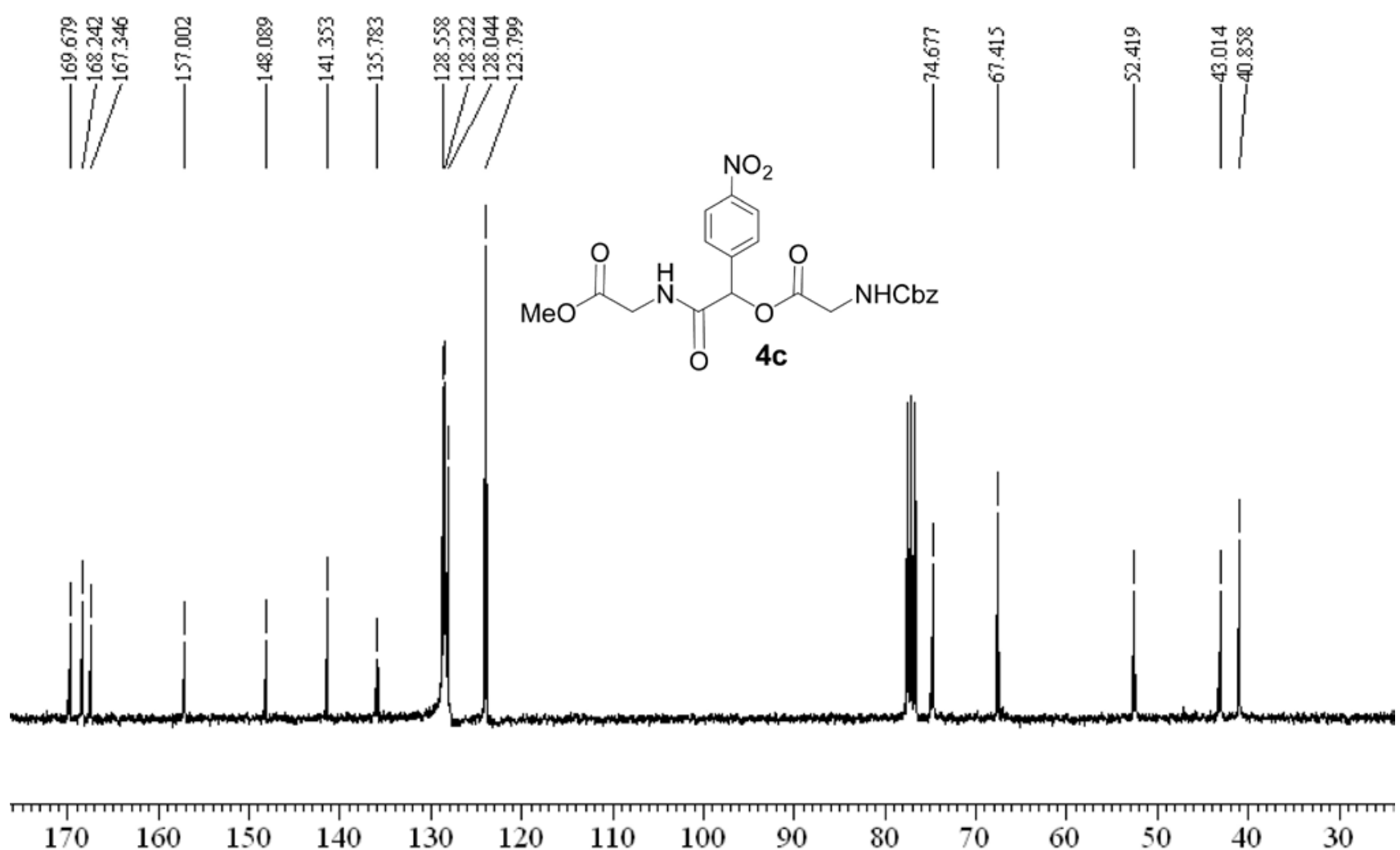

Figure S11. ${ }^{13} \mathrm{C} \mathrm{NMR}\left(\mathrm{CDCl}_{3}, 75 \mathrm{MHz}\right)$ of $\mathbf{4 c}$. 


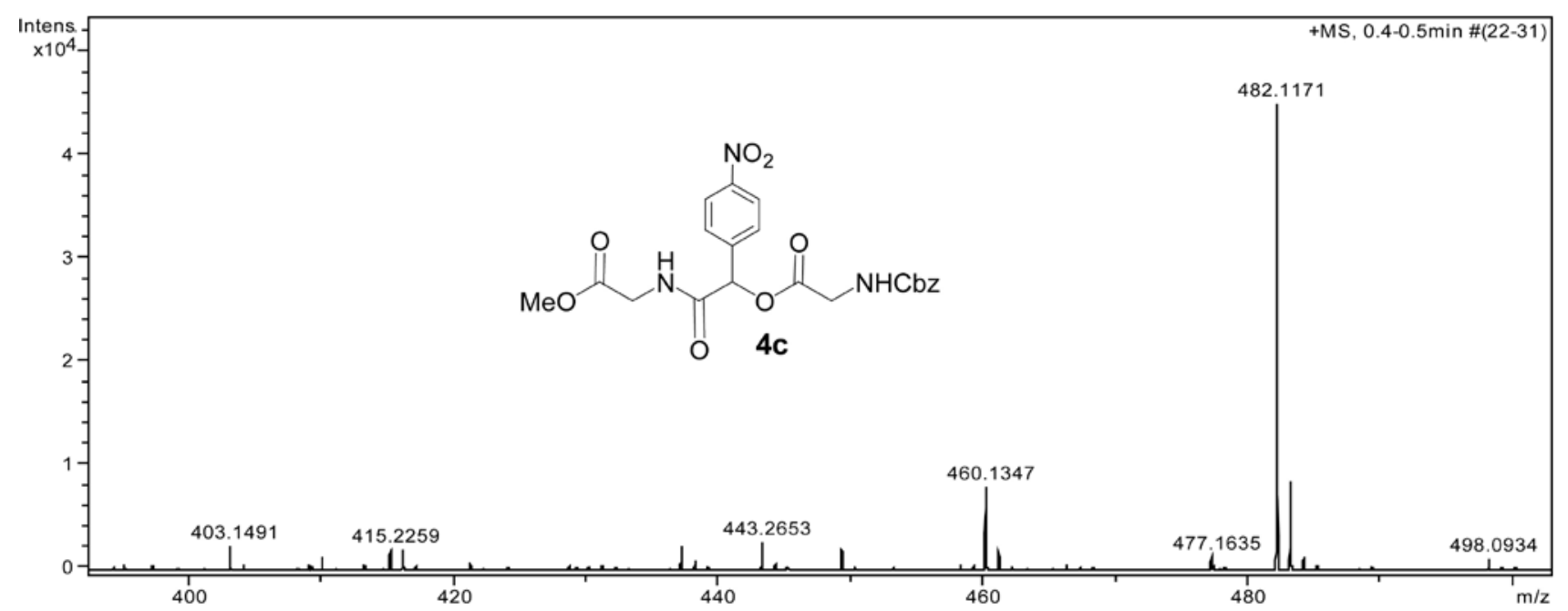

Figure S12. ESI-HRMS of 4c.

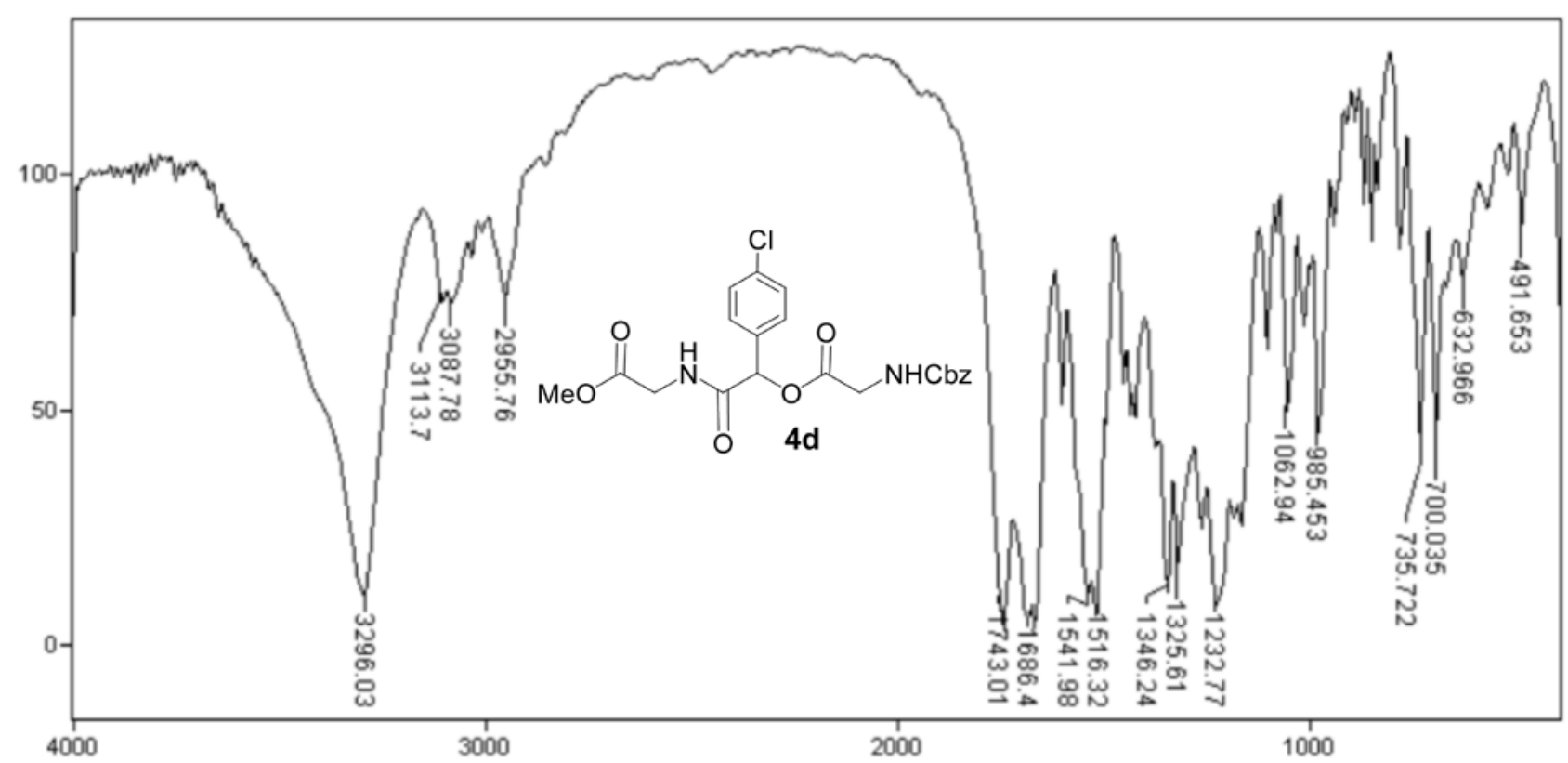

Figure S13. IR spectrum of $\mathbf{4 d}$. 

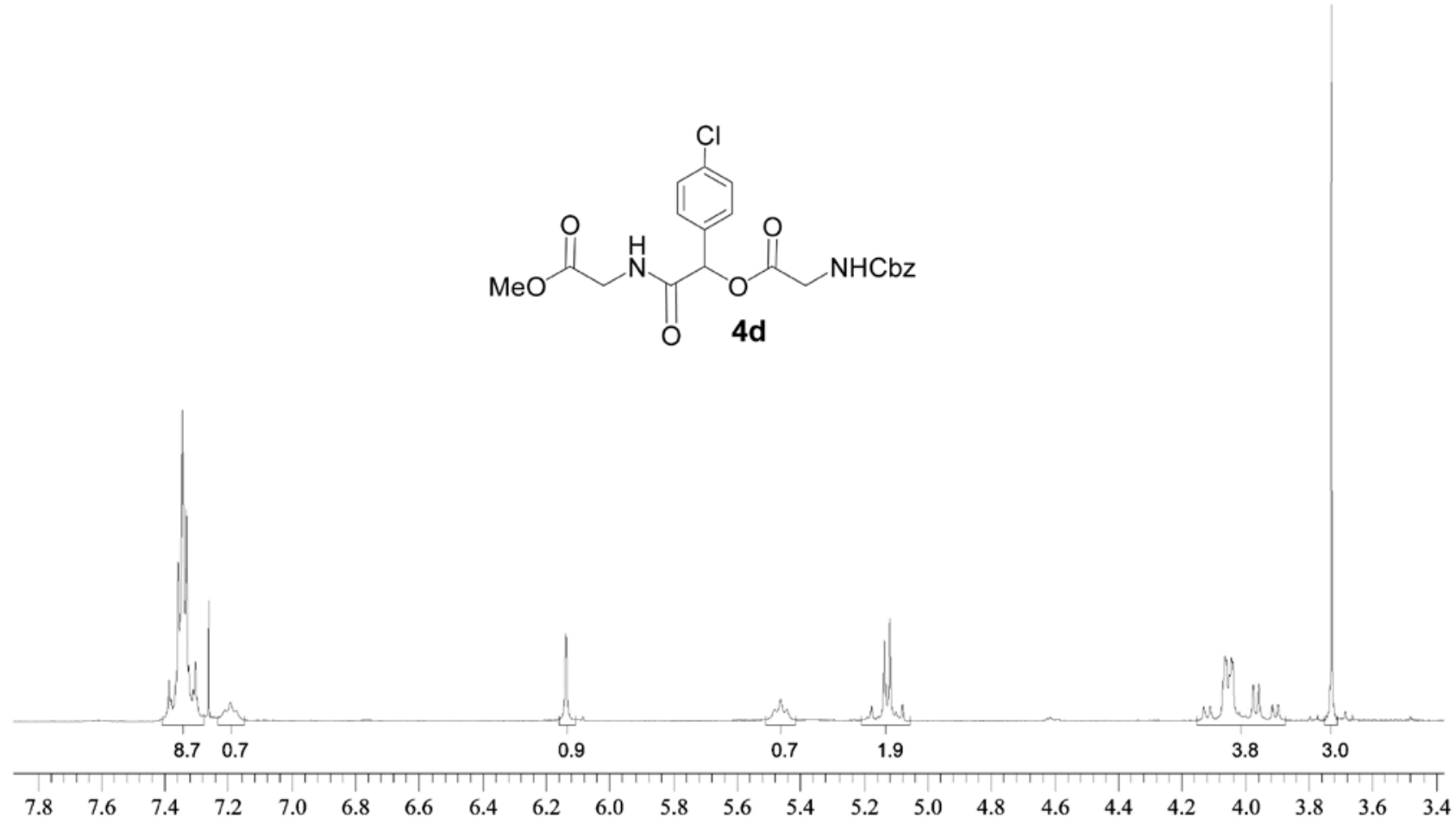

Figure S14. ${ }^{1} \mathrm{H} \mathrm{NMR}\left(\mathrm{CDCl}_{3}, 300 \mathrm{MHz}\right)$ of $\mathbf{4 d}$. Note: The number below each peak refers to the number of integration.
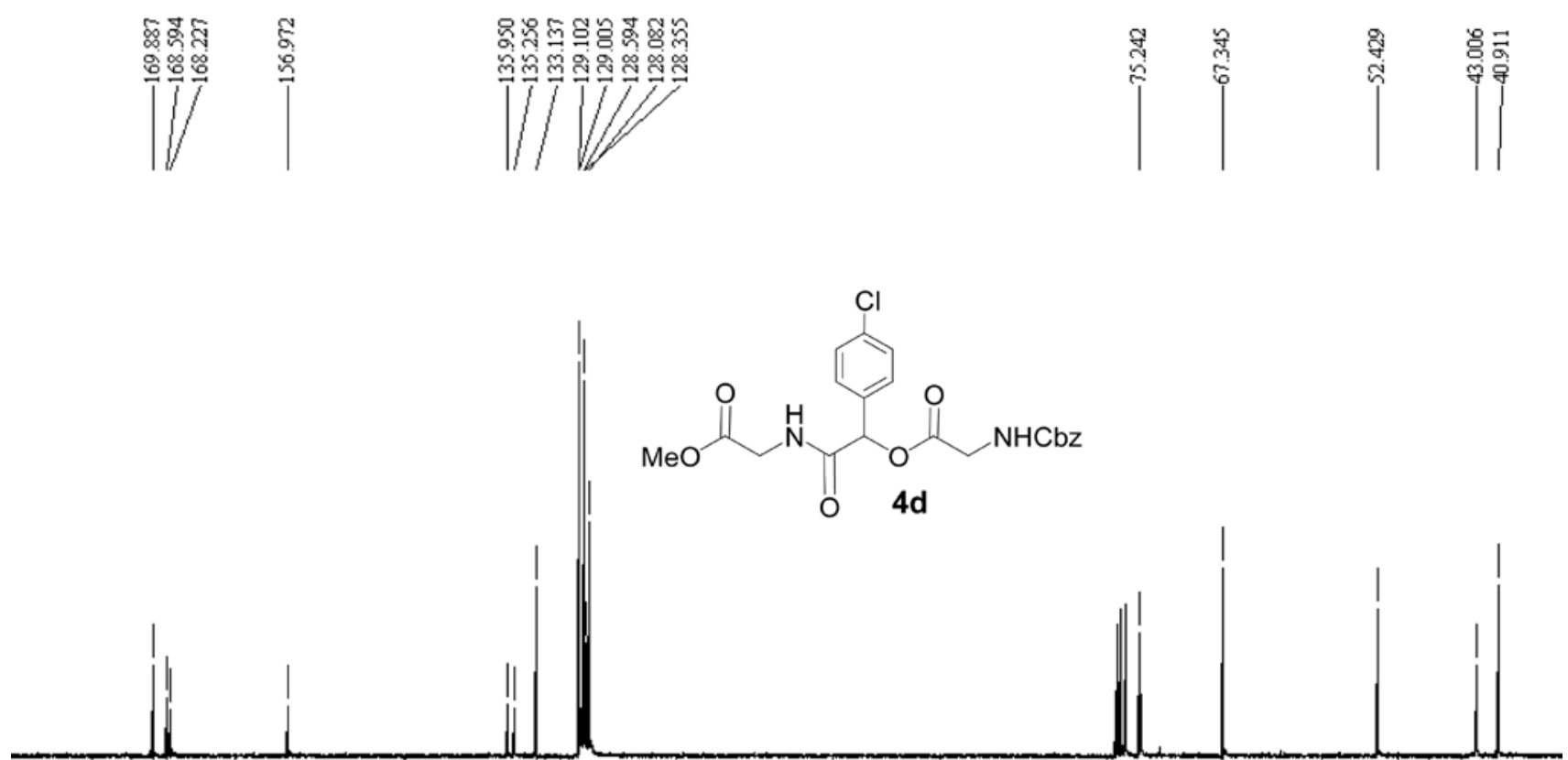

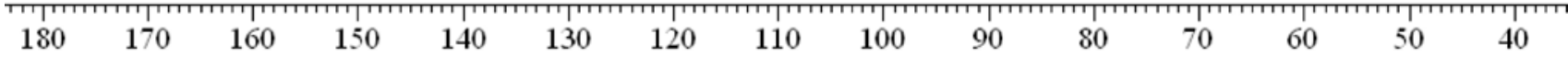

Figure S15. ${ }^{13} \mathrm{C} \mathrm{NMR}\left(\mathrm{CDCl}_{3}, 75 \mathrm{MHz}\right)$ of $\mathbf{4 d}$. 


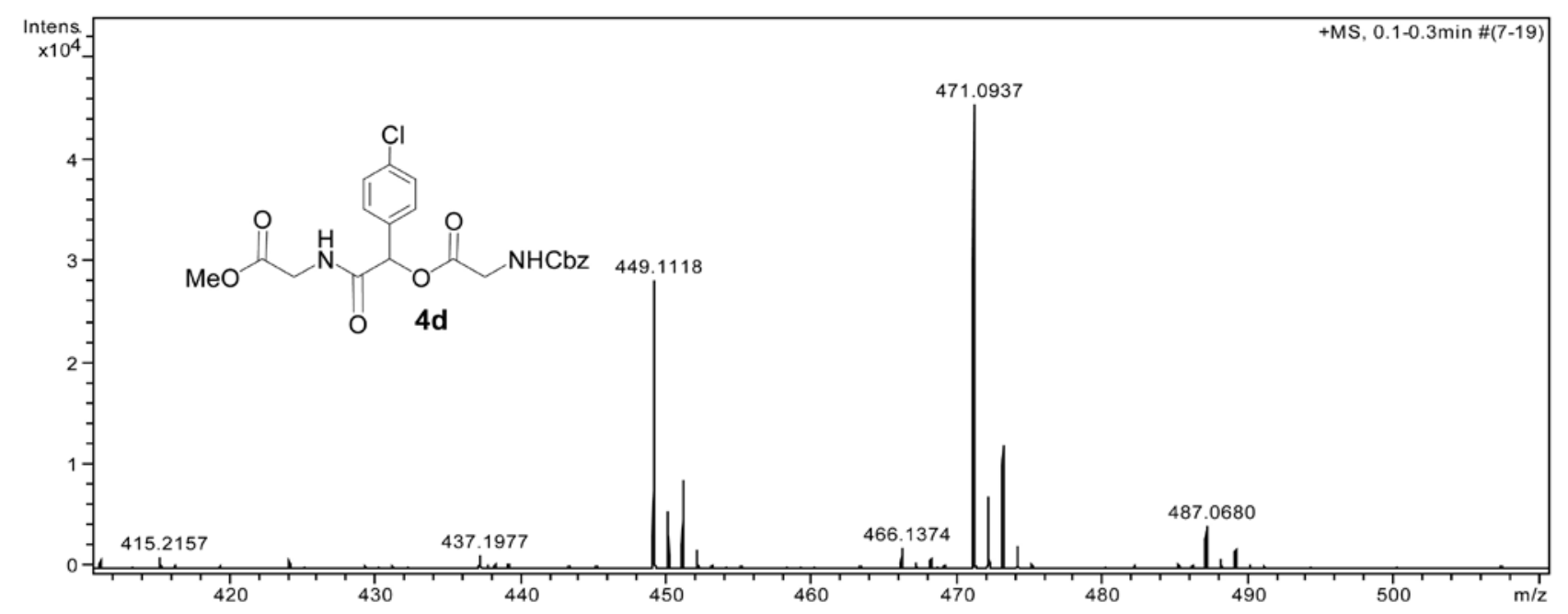

Figure S16. ESI-HRMS of 4d.

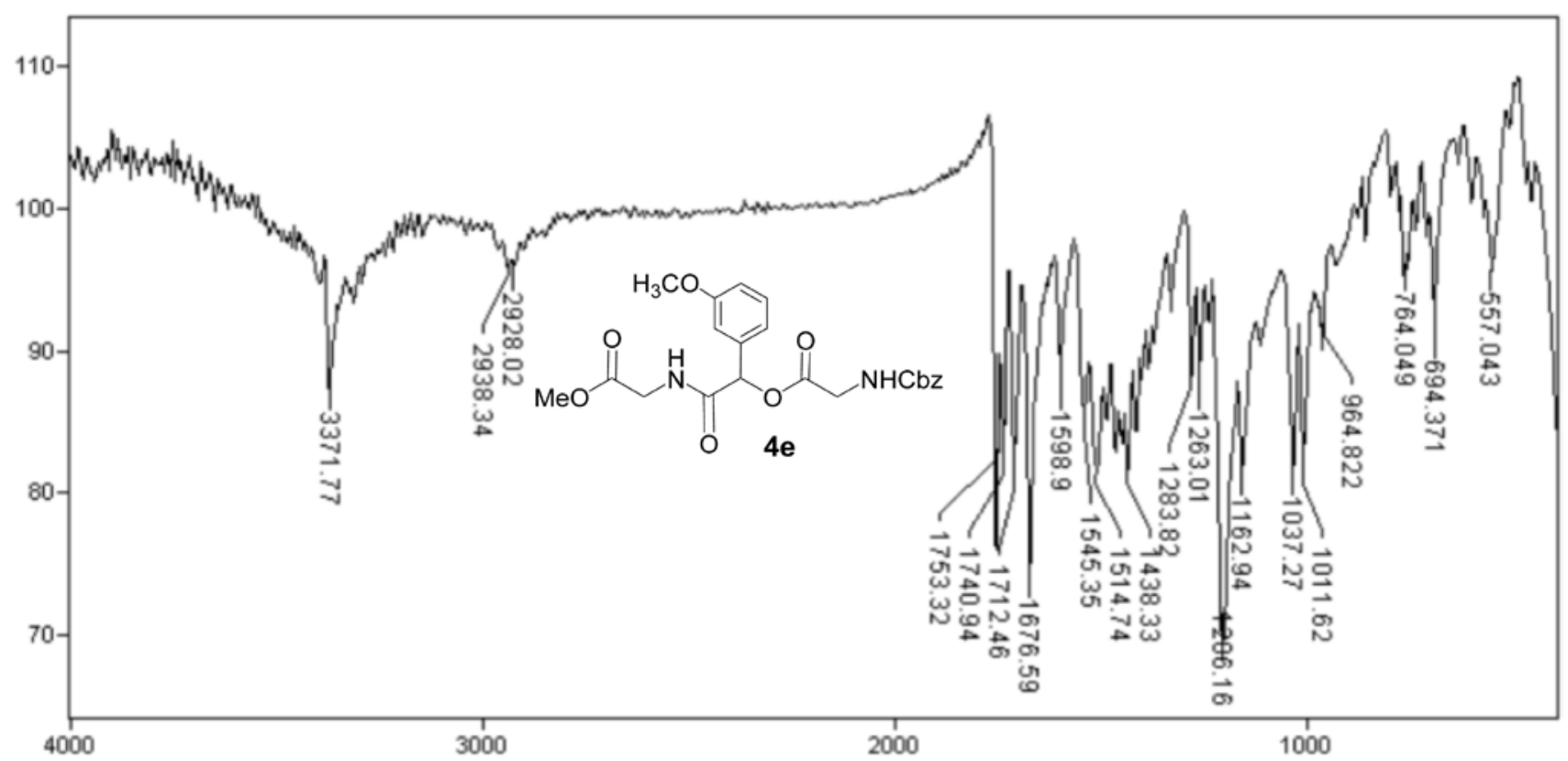

Figure S17. IR spectrum of $4 \mathbf{e}$. 

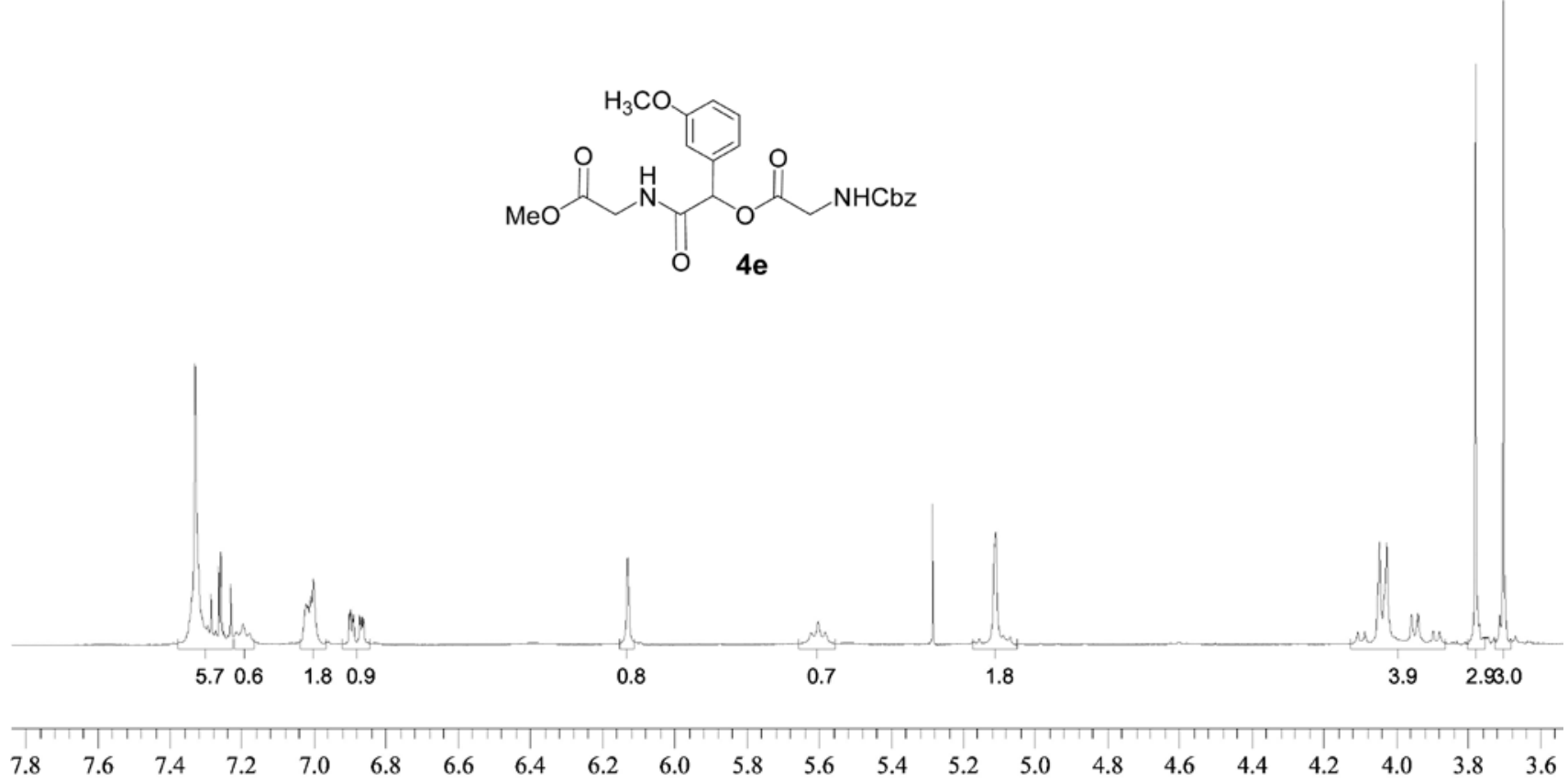

Figure S18. ${ }^{1} \mathrm{H}$ NMR $\left(\mathrm{CDCl}_{3}, 300 \mathrm{MHz}\right)$ of 4e. Note: The number below each peak refers to the number of integration.
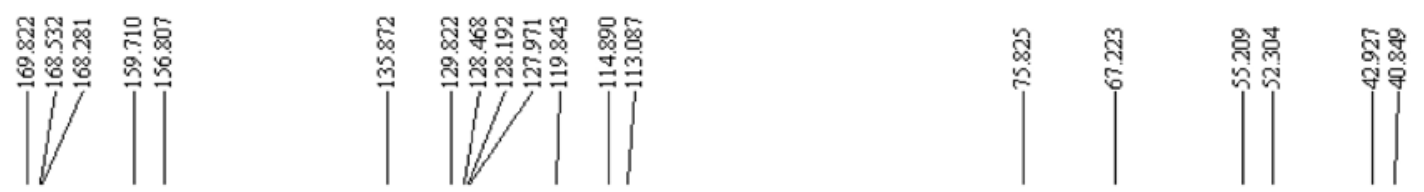<smiles>COC(=O)CNCC(=O)OC(C(=O)NCC(=O)OC)c1cccc(OC)c1</smiles>
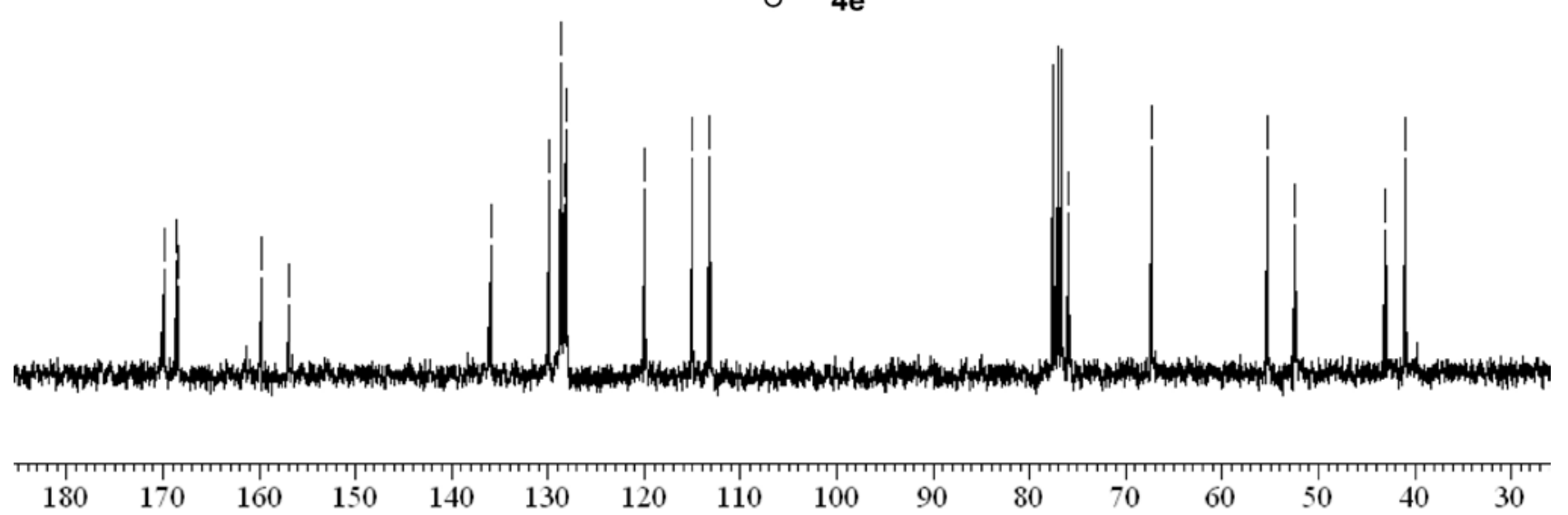

Figure S19. ${ }^{13} \mathrm{C} \mathrm{NMR}\left(\mathrm{CDCl}_{3}, 75 \mathrm{MHz}\right)$ of $4 \mathbf{e}$. 


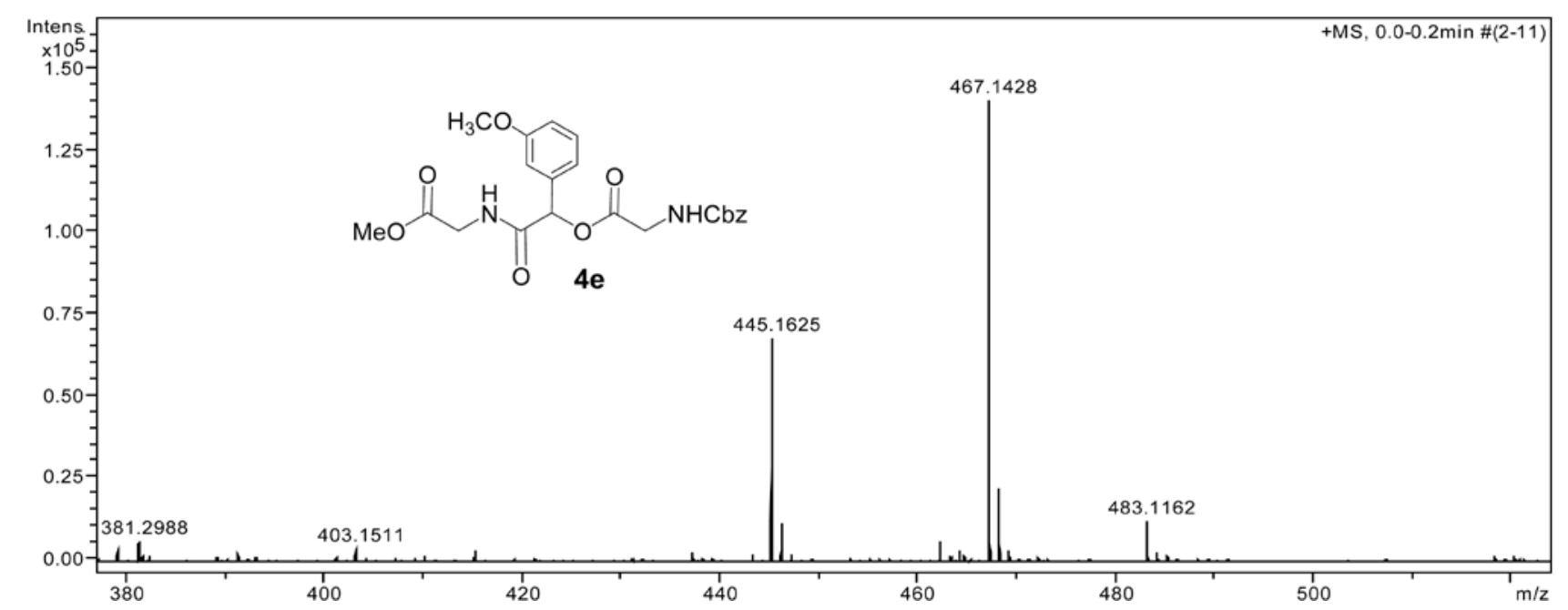

Figure S20. ESI-HRMS of $4 \mathbf{e}$.

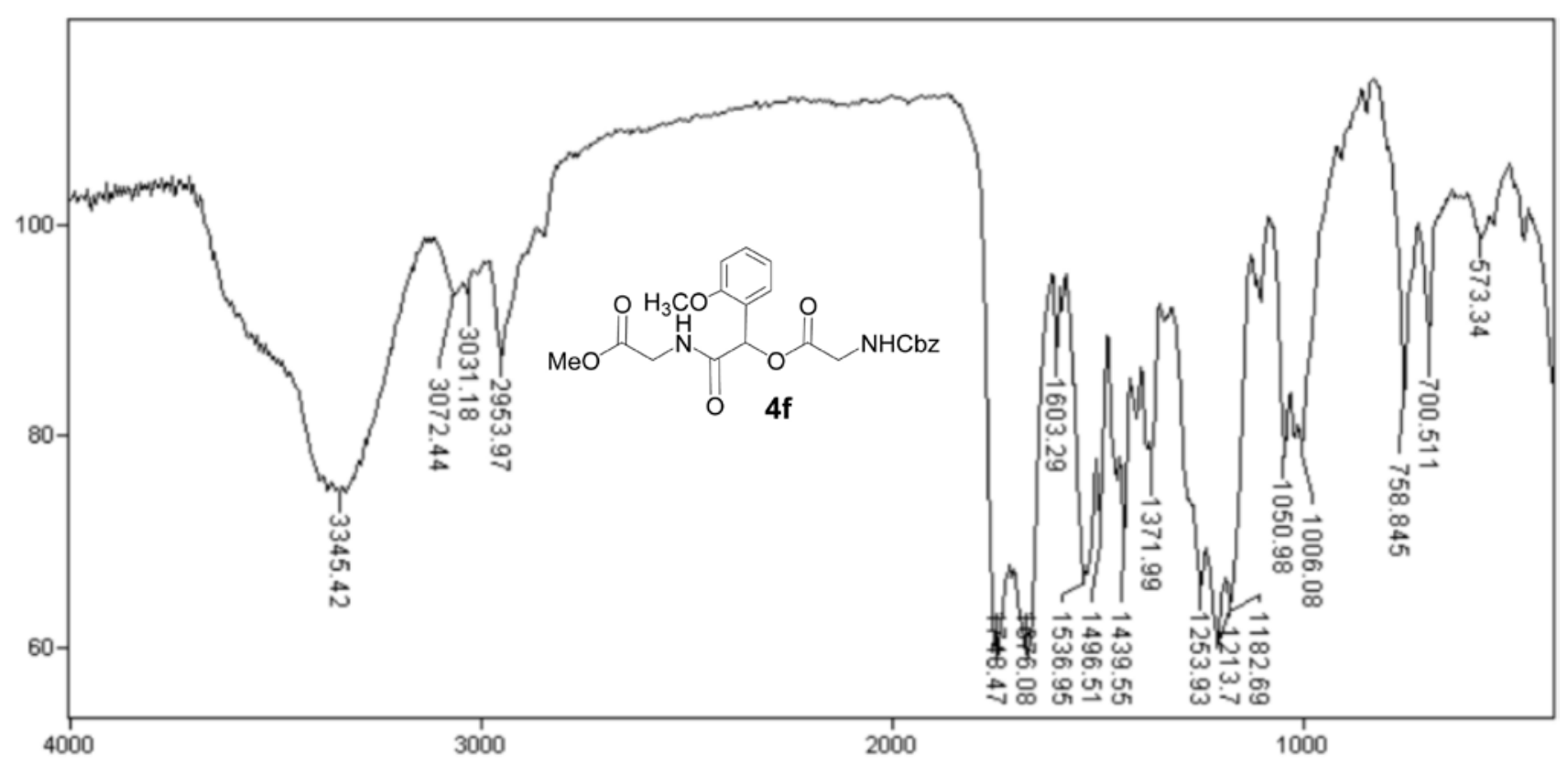

Figure S21. IR spectrum of $\mathbf{4 f}$. 


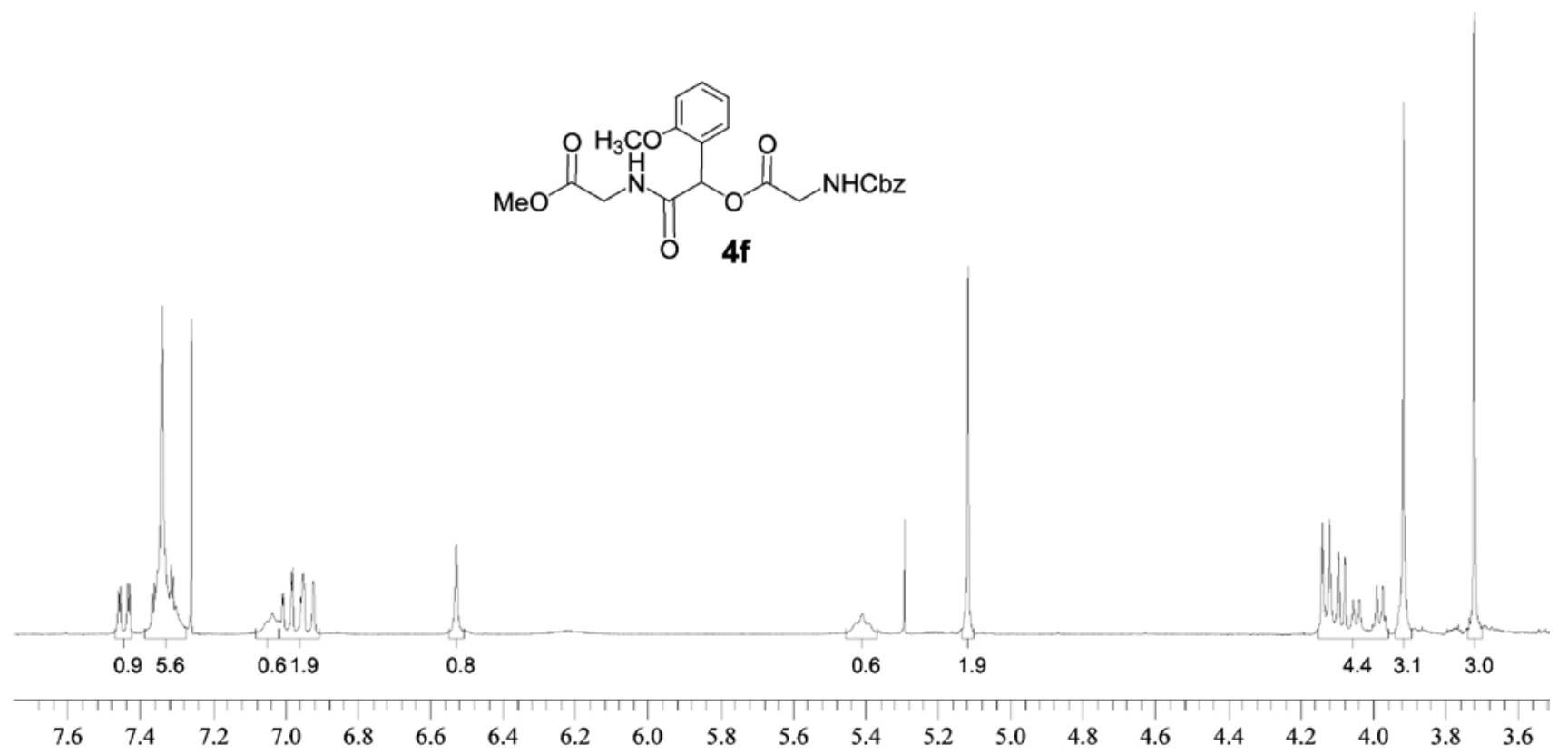

Figure S22. ${ }^{1} \mathrm{H}$ NMR $\left(\mathrm{CDCl}_{3}, 300 \mathrm{MHz}\right)$ of $\mathbf{4 f}$. Note: The number below each peak refers to the number of integration.
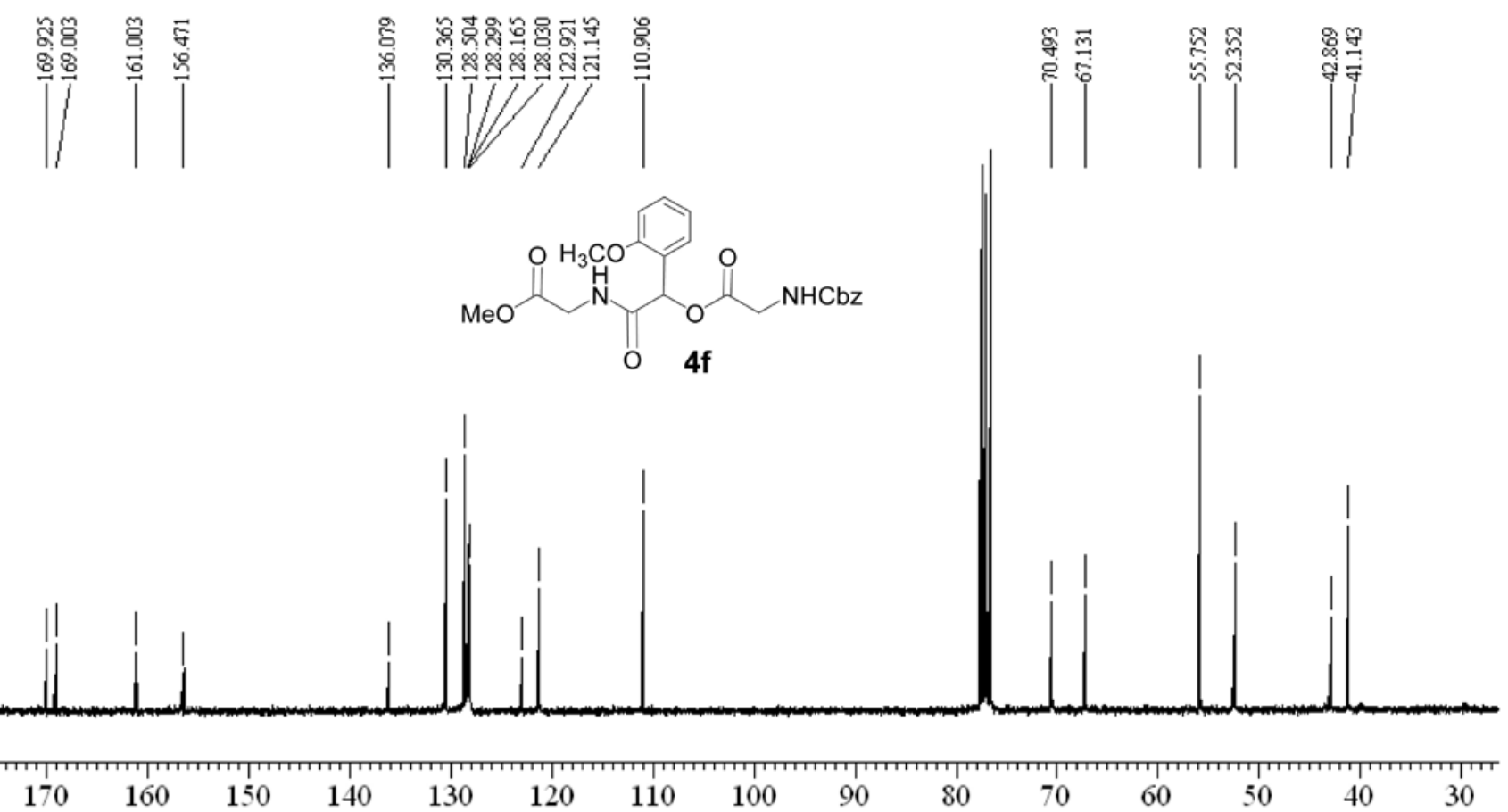

Figure S23. ${ }^{13} \mathrm{C}$ NMR $\left(\mathrm{CDCl}_{3}, 75 \mathrm{MHz}\right)$ of $\mathbf{4 f}$. 


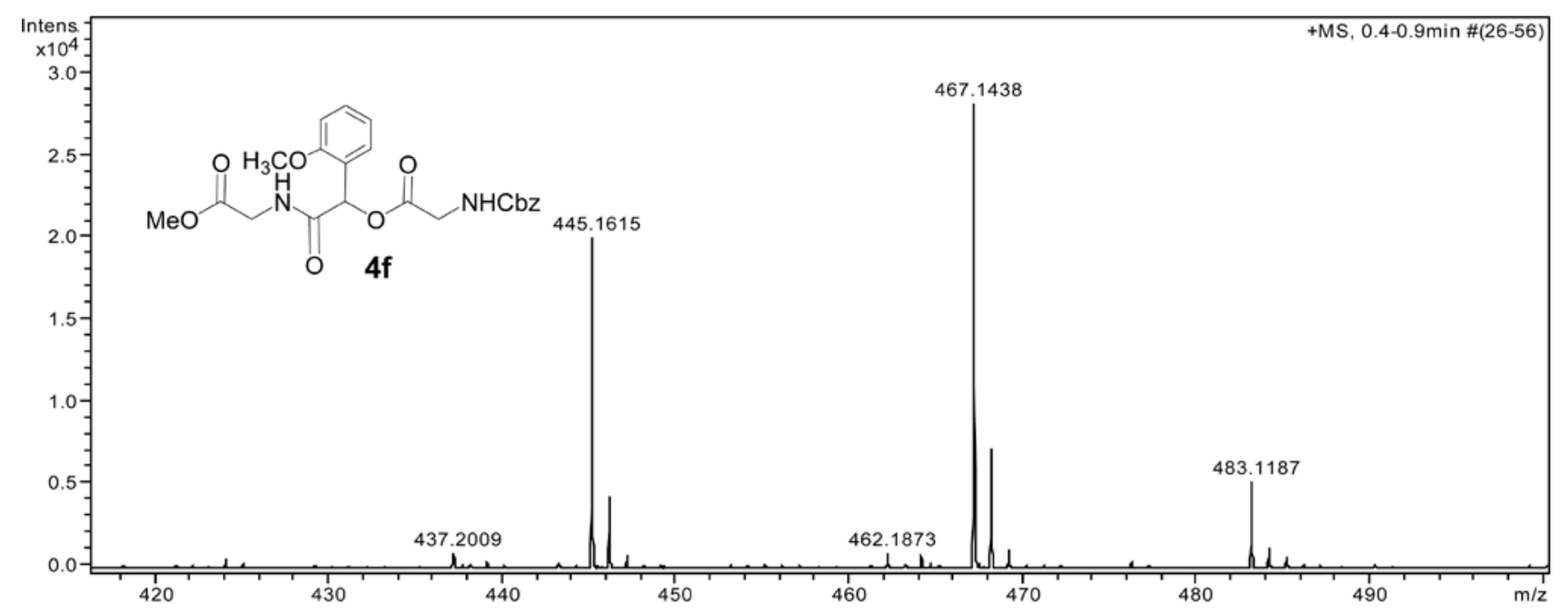

Figure S24. ESI-HRMS of 4 f.

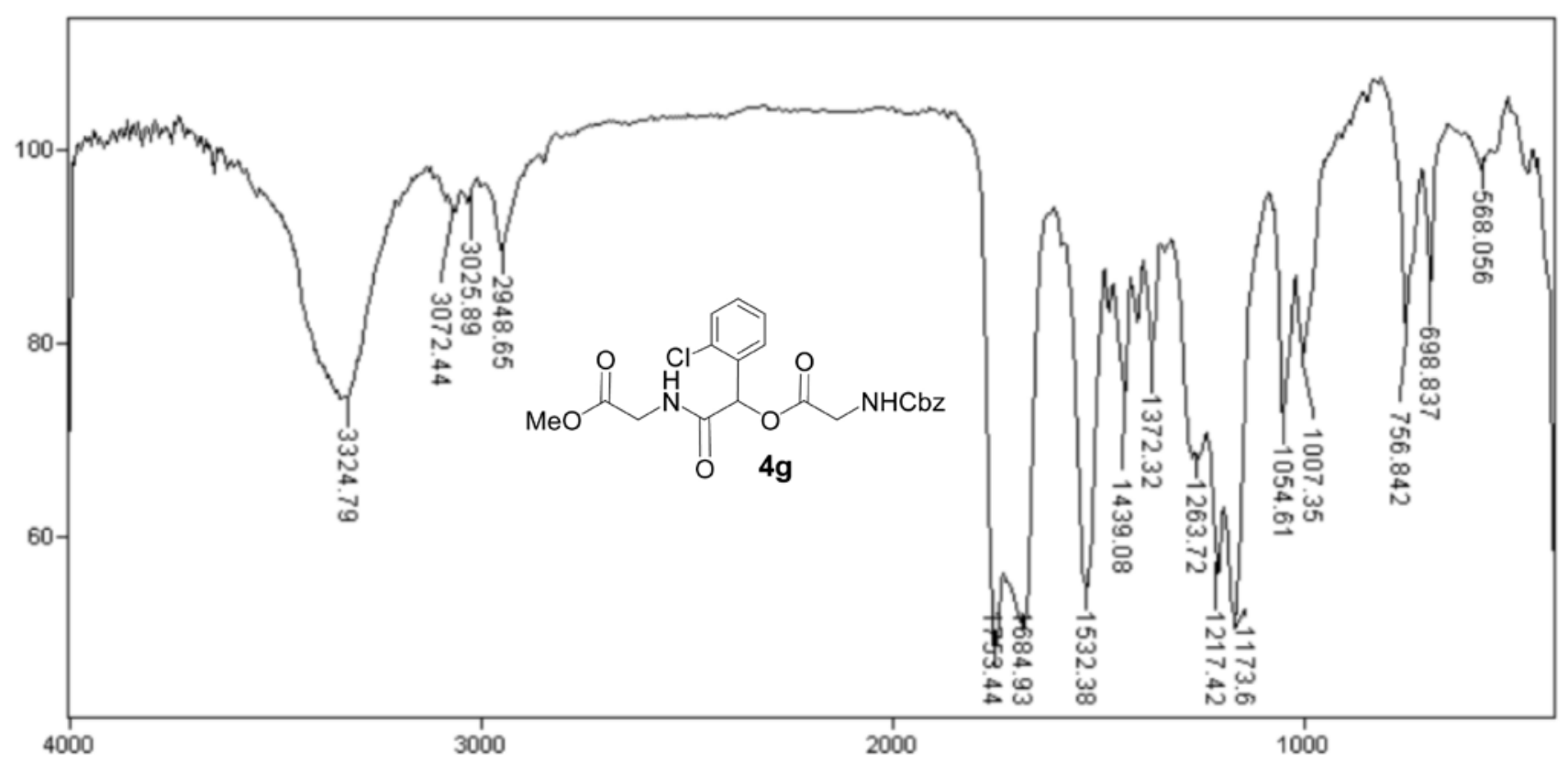

Figure S25. IR spectrum of $\mathbf{4 g}$. 
<smiles>COC(=O)CNC(=O)C(=O)OC(C(=O)NCC(=O)OC)c1ccccc1Cl</smiles>

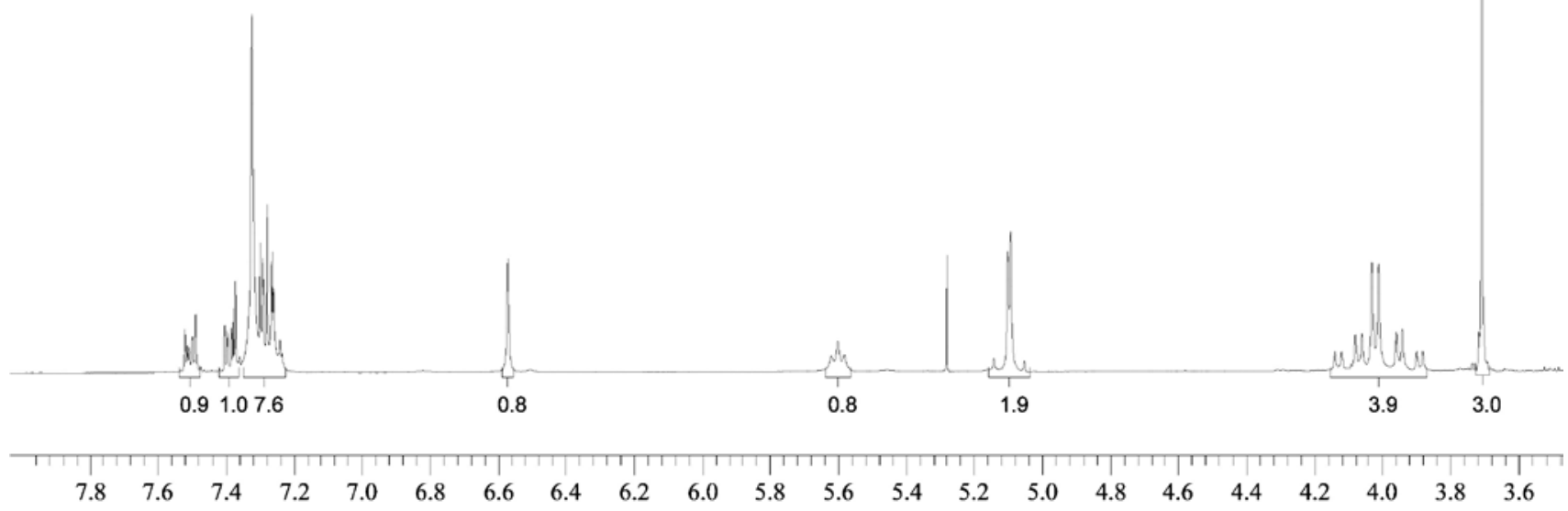

Figure S26. ${ }^{1} \mathrm{H}$ NMR $\left(\mathrm{CDCl}_{3}, 300 \mathrm{MHz}\right)$ of $\mathbf{4 g}$. Note: The number below each peak refers to the number of integration.
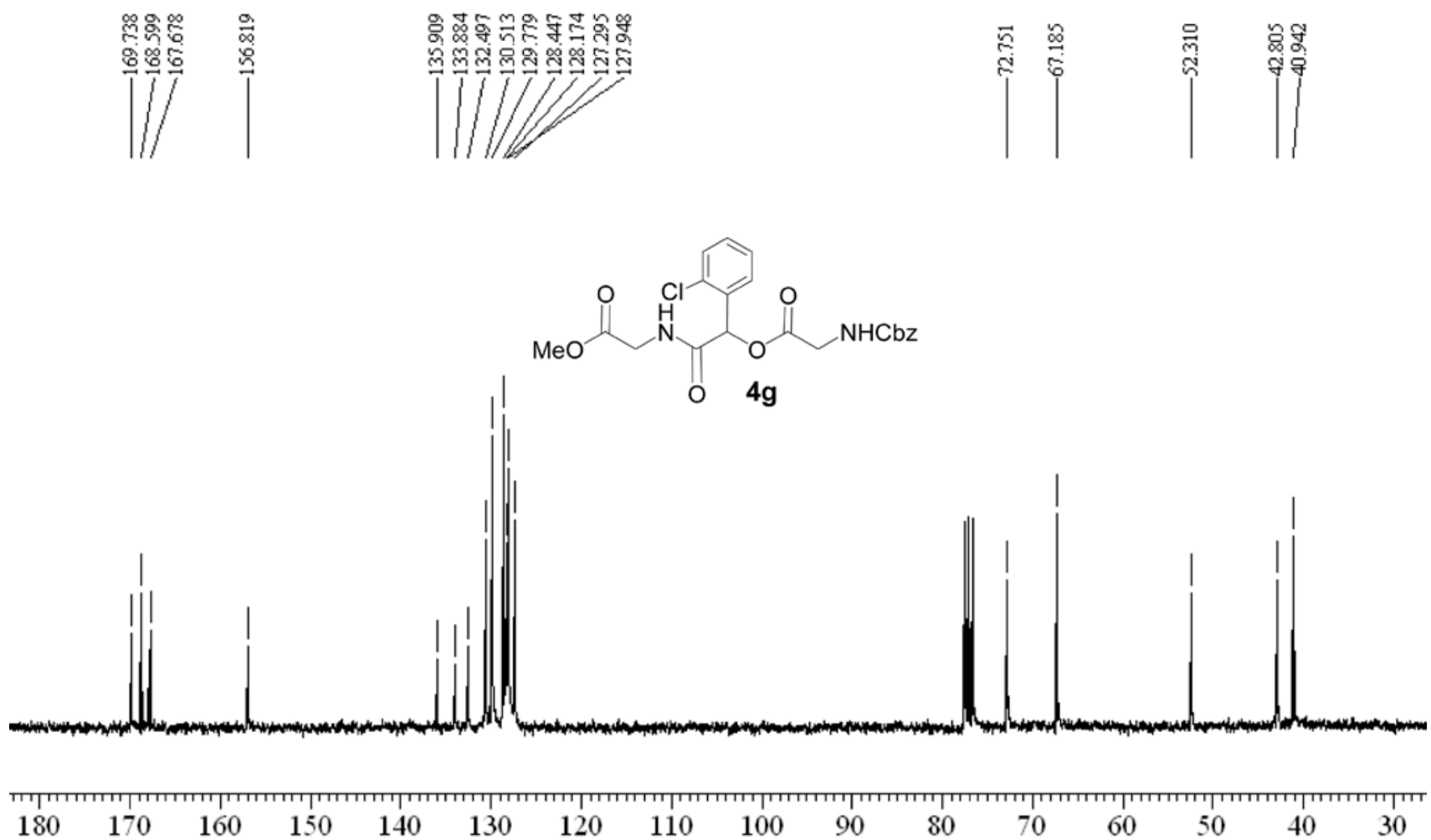

Figure S27. ${ }^{13} \mathrm{C} \mathrm{NMR}\left(\mathrm{CDCl}_{3}, 75 \mathrm{MHz}\right)$ of $\mathbf{4 g}$. 


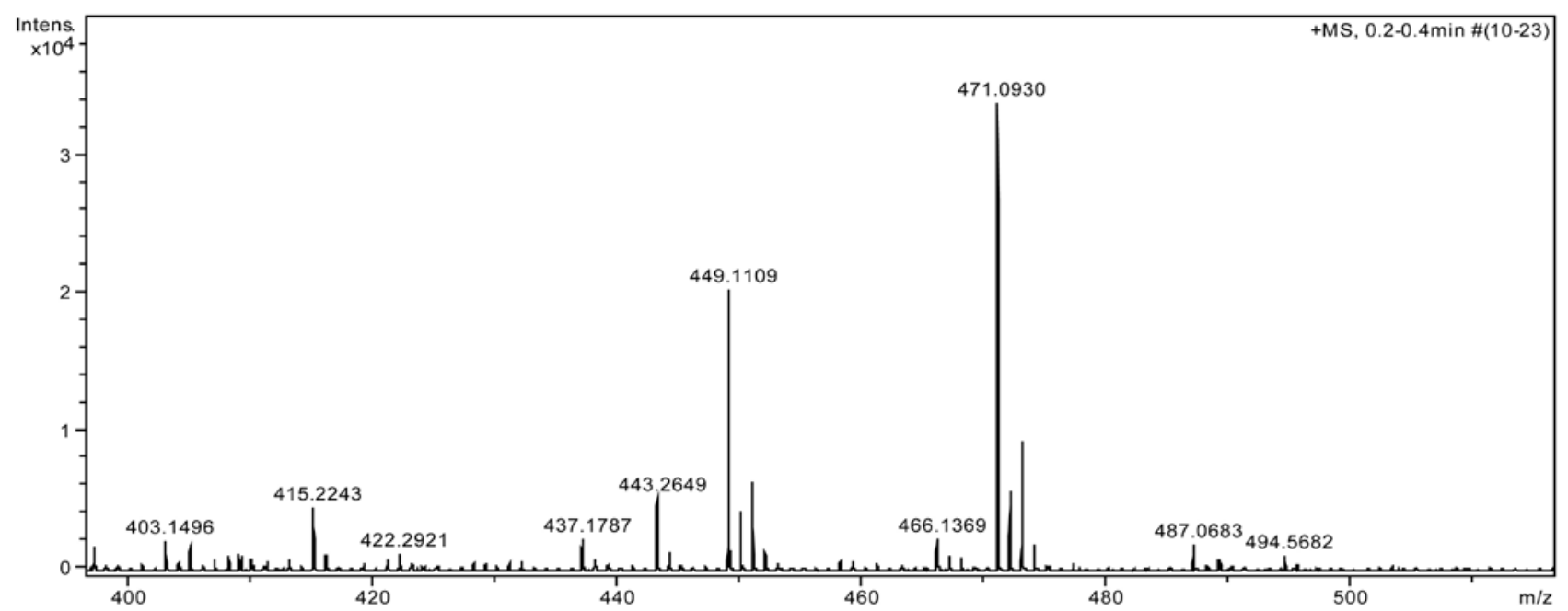

Figure S28. ESI-HRMS of 4g.

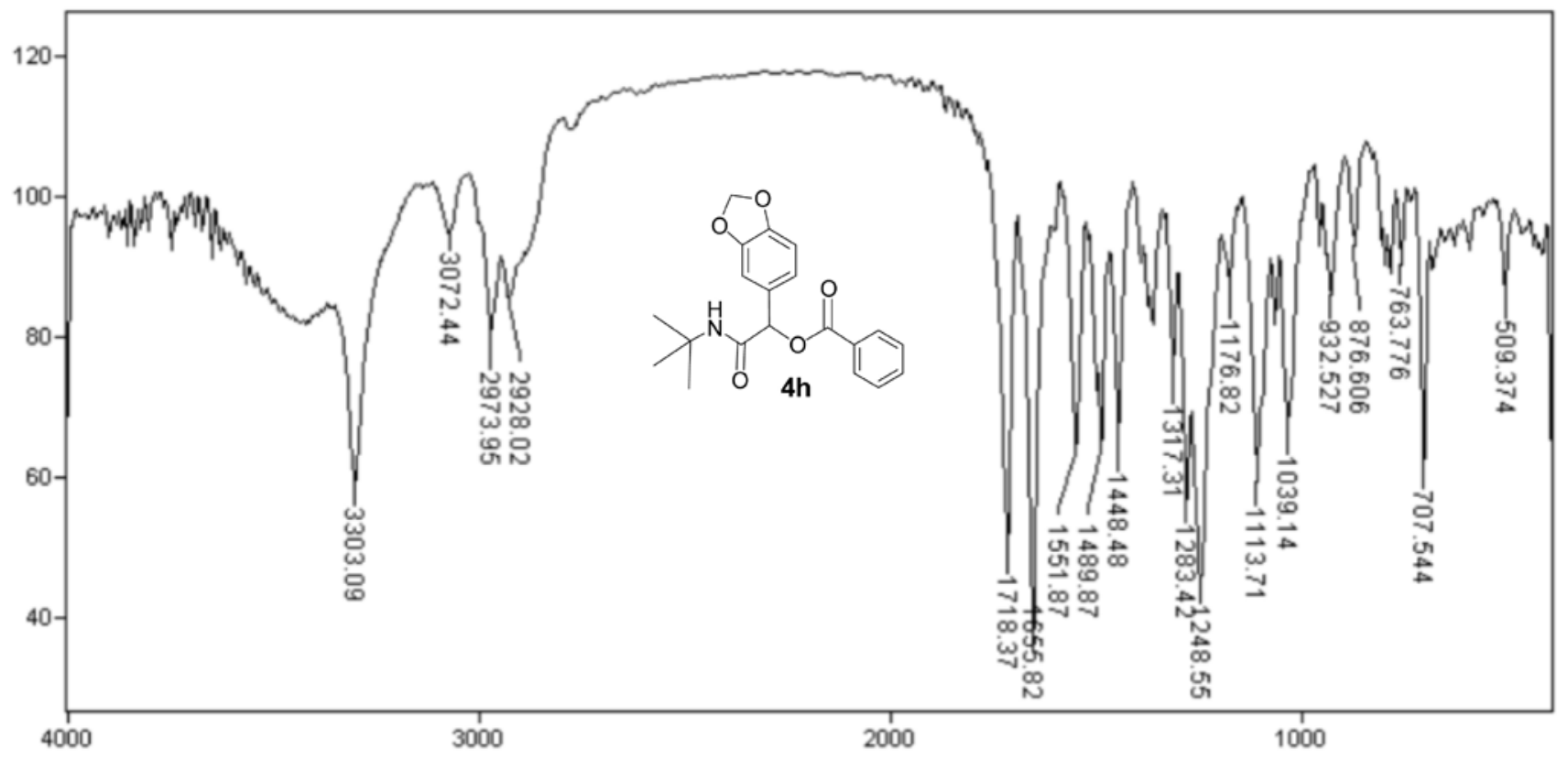

Figure S29. IR spectrum of $\mathbf{4 h}$. 


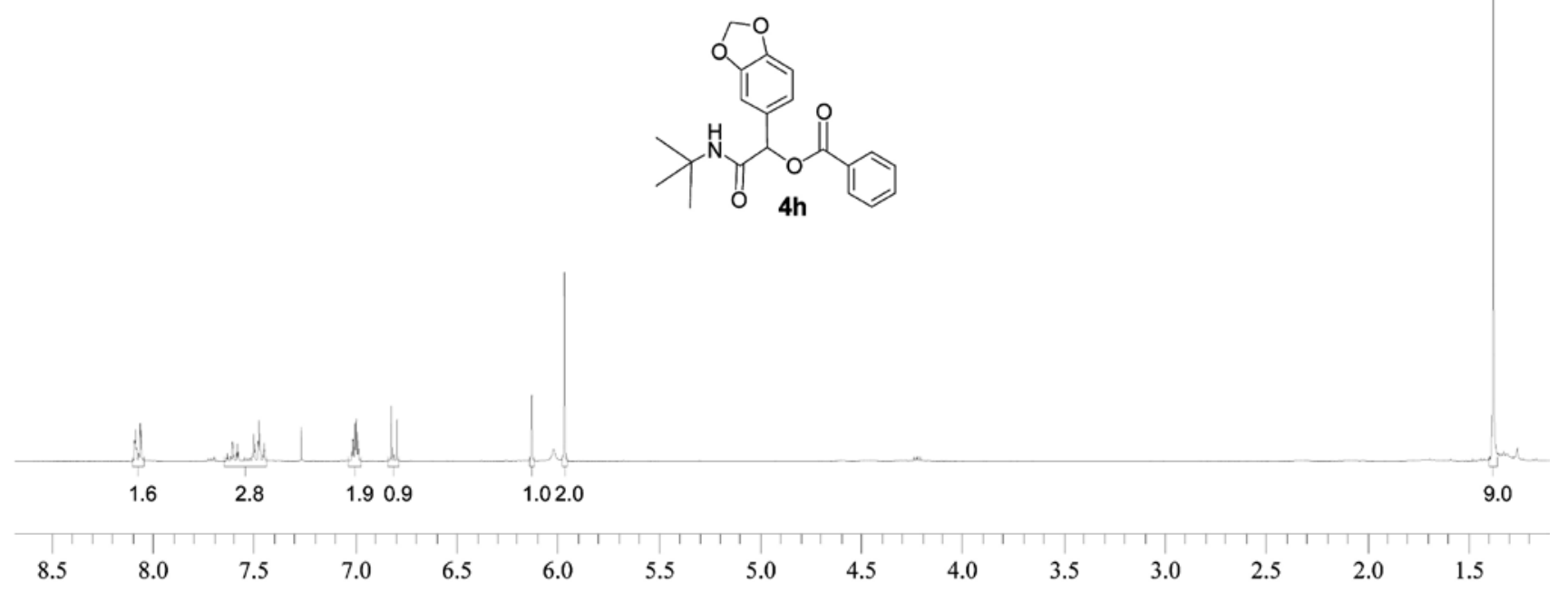

Figure S30. ${ }^{1} \mathrm{H}$ NMR $\left(\mathrm{CDCl}_{3}, 300 \mathrm{MHz}\right)$ of $\mathbf{4 h}$. Note: The number below each peak refers to the number of integration.
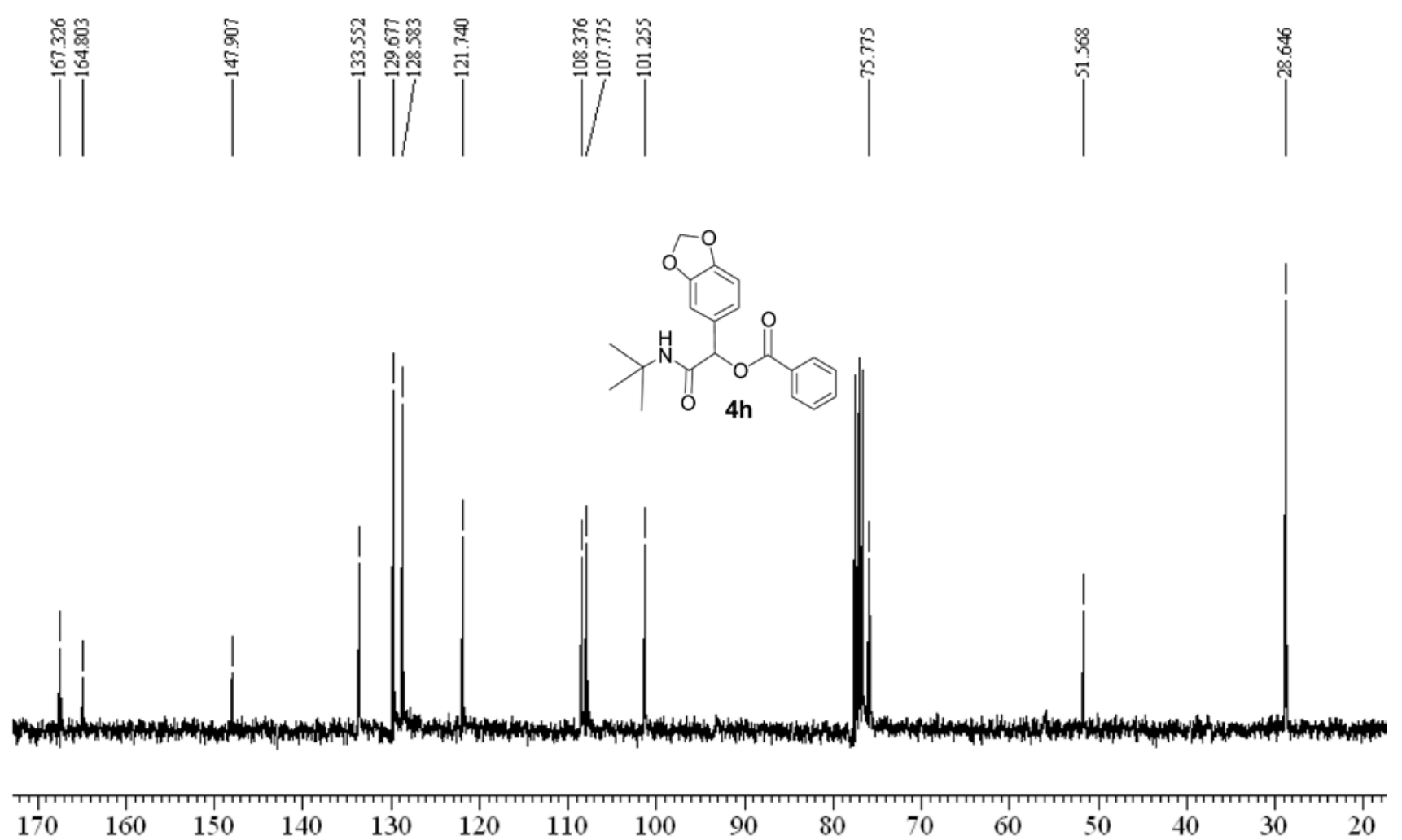

Figure S31. ${ }^{13} \mathrm{C}$ NMR $\left(\mathrm{CDCl}_{3}, 75 \mathrm{MHz}\right)$ of $\mathbf{4 h}$. 


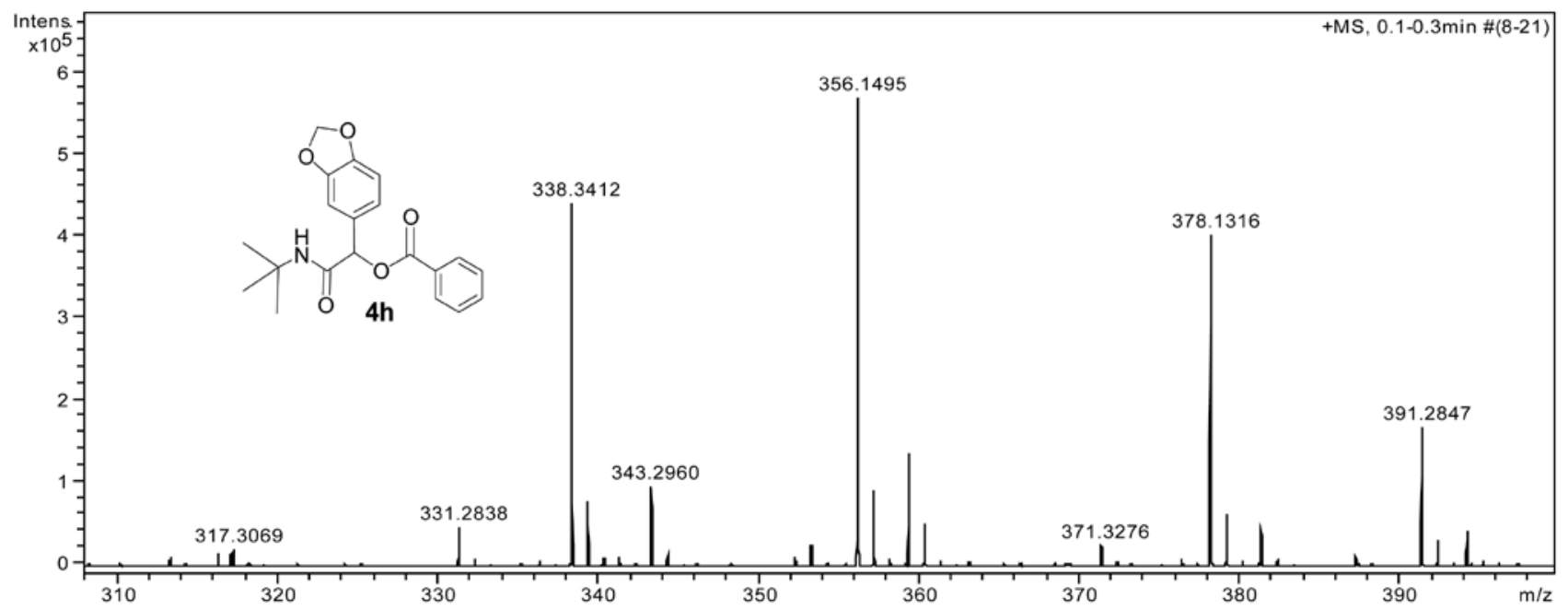

Figure S32. ESI-HRMS of $\mathbf{4 h}$.

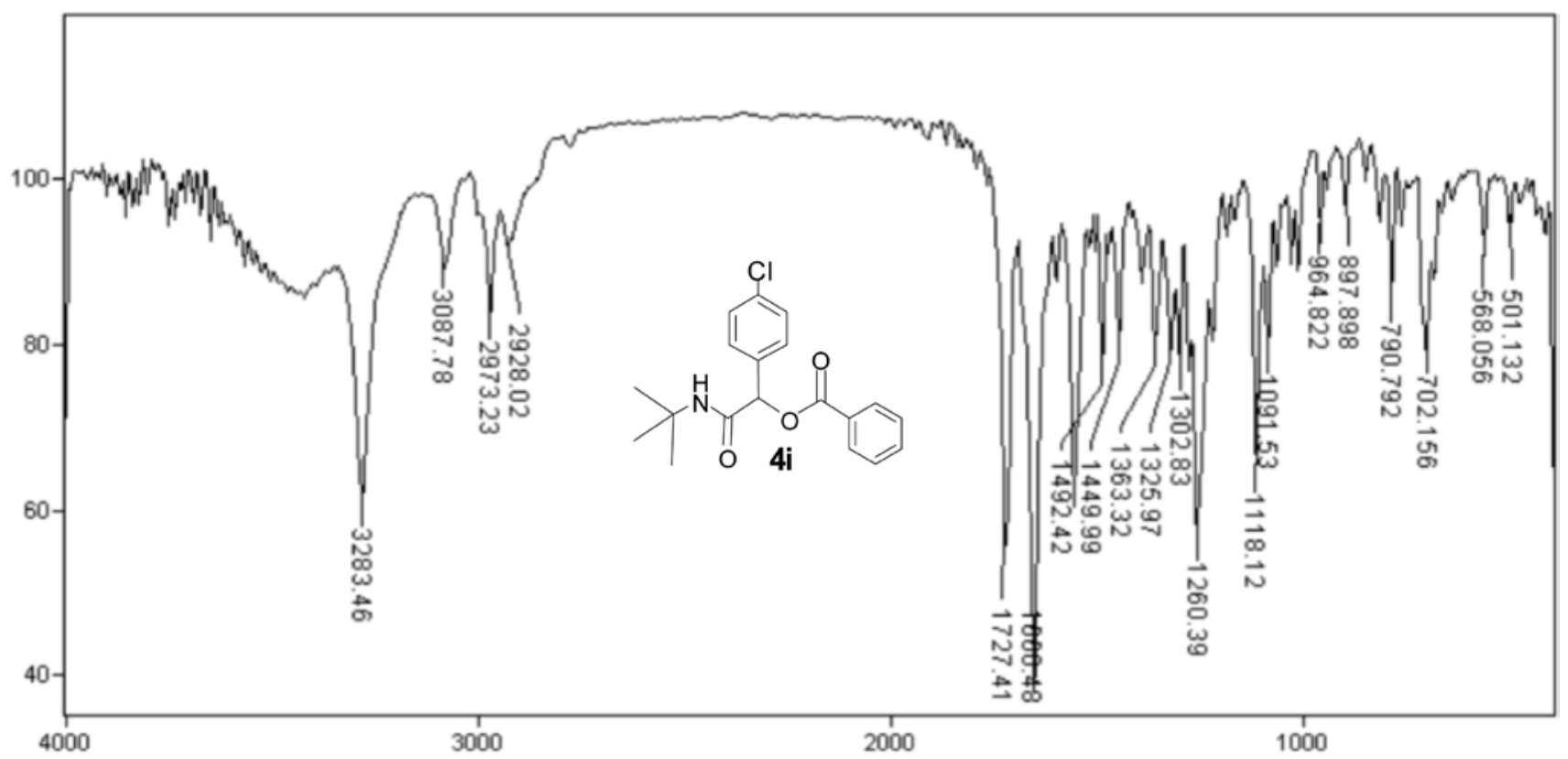

Figure S33. IR spectrum of 4 i. 


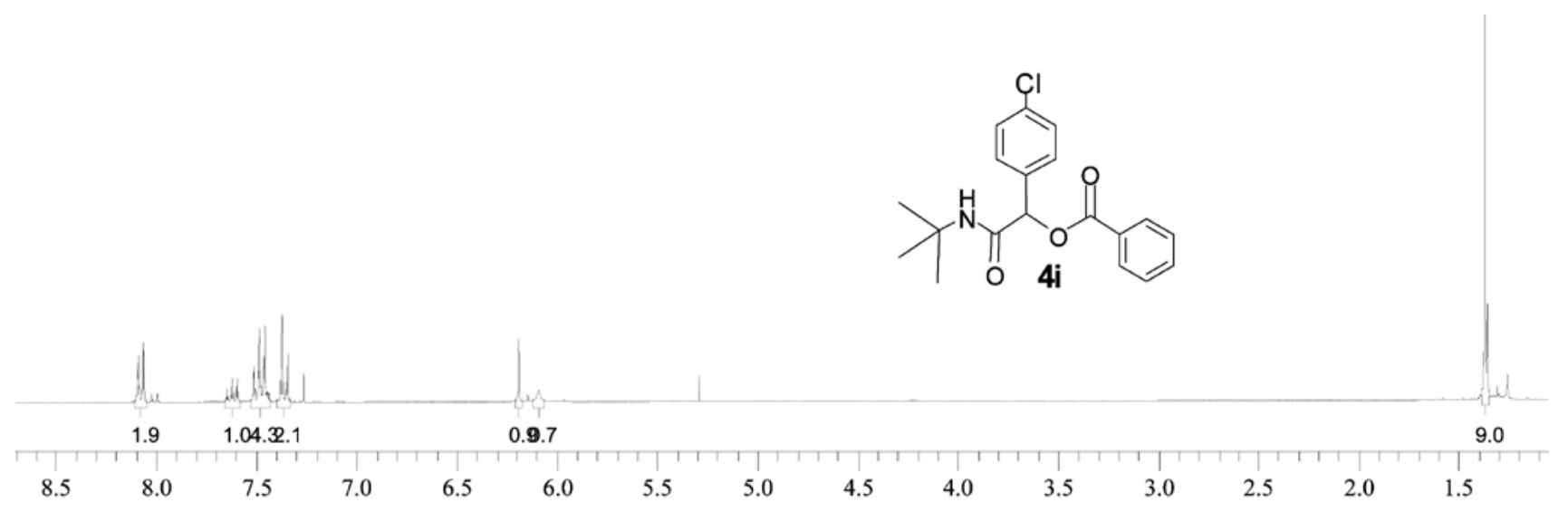

Figure S34. ${ }^{1} \mathrm{H}$ NMR $\left(\mathrm{CDCl}_{3}, 300 \mathrm{MHz}\right)$ of $4 \mathrm{i}$. Note: The number below each peak refers to the number of integration.

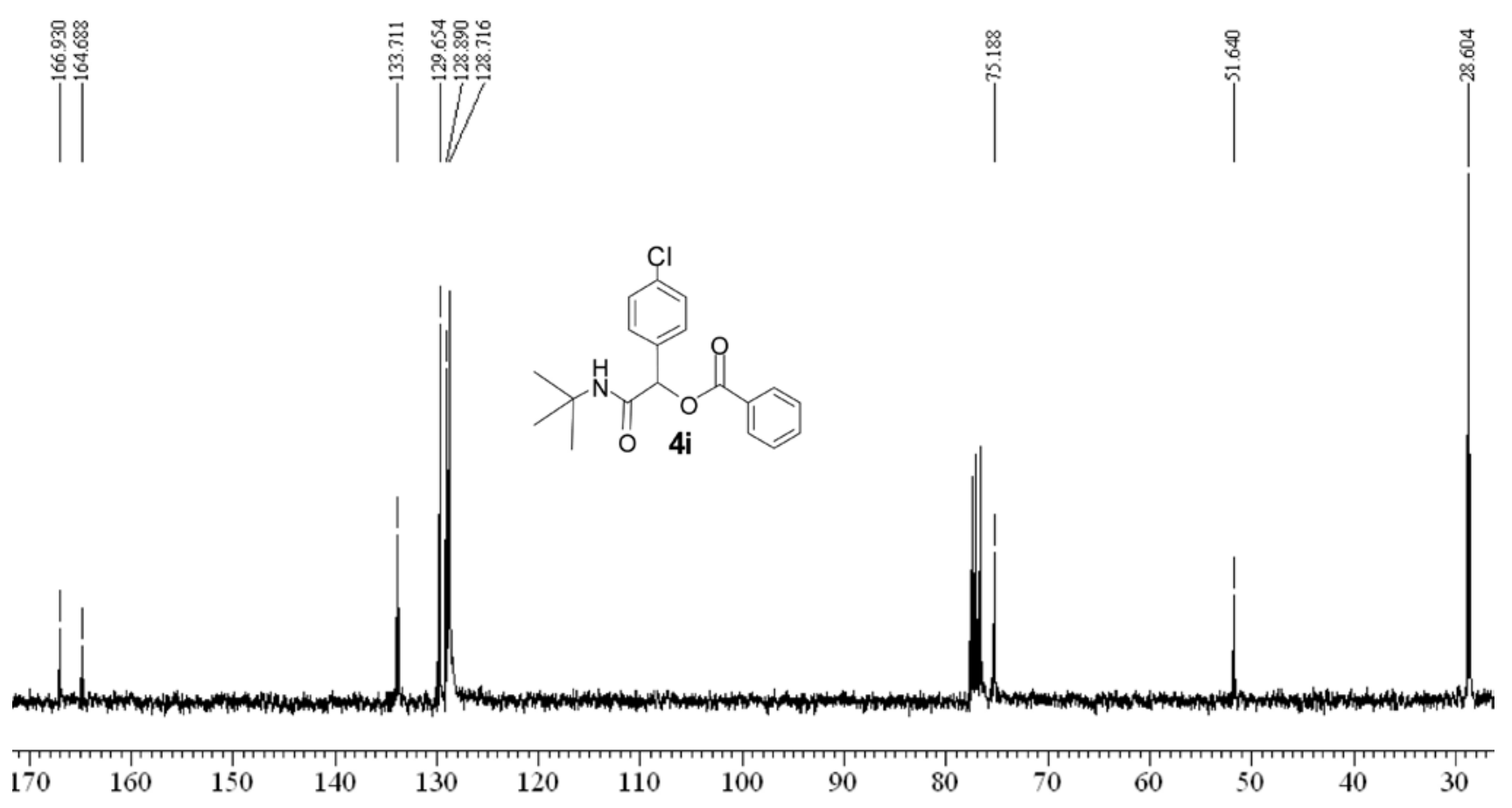

Figure S35. ${ }^{13} \mathrm{C}$ NMR $\left(\mathrm{CDCl}_{3}, 75 \mathrm{MHz}\right)$ of $4 \mathbf{i}$. 


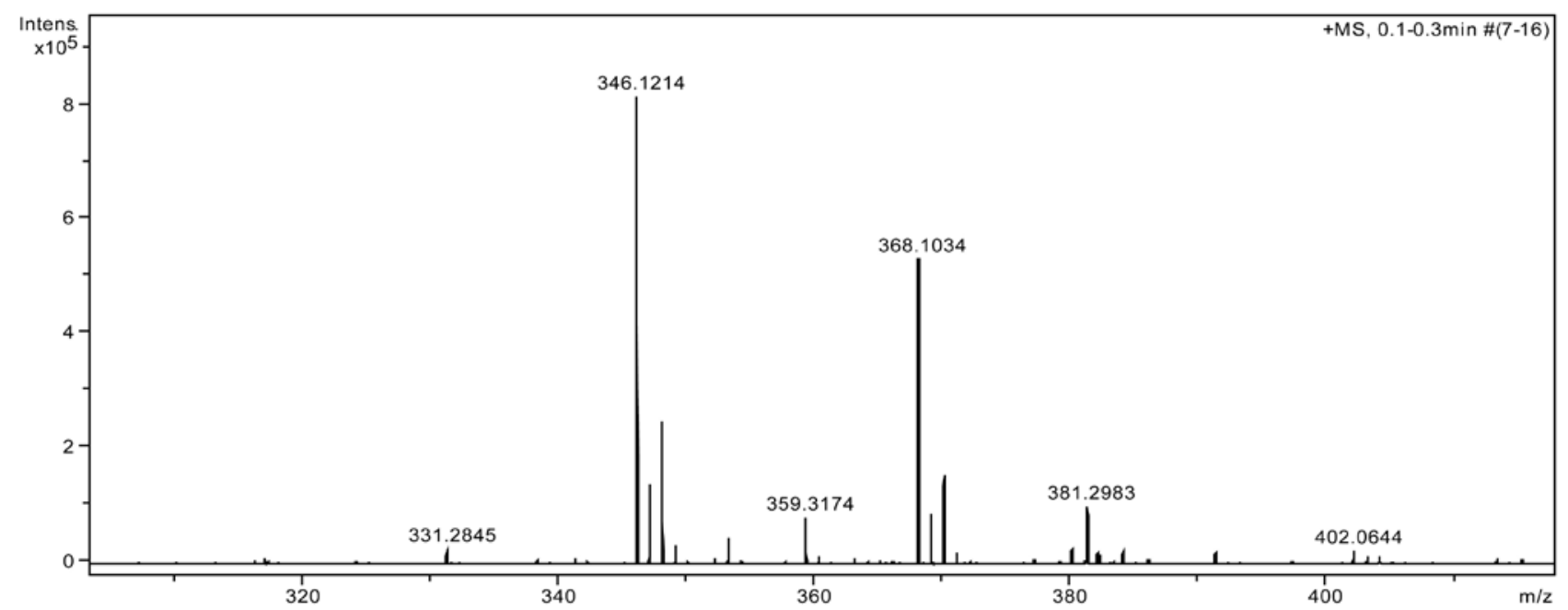

Figure S36. ESI-HRMS of $4 i$.

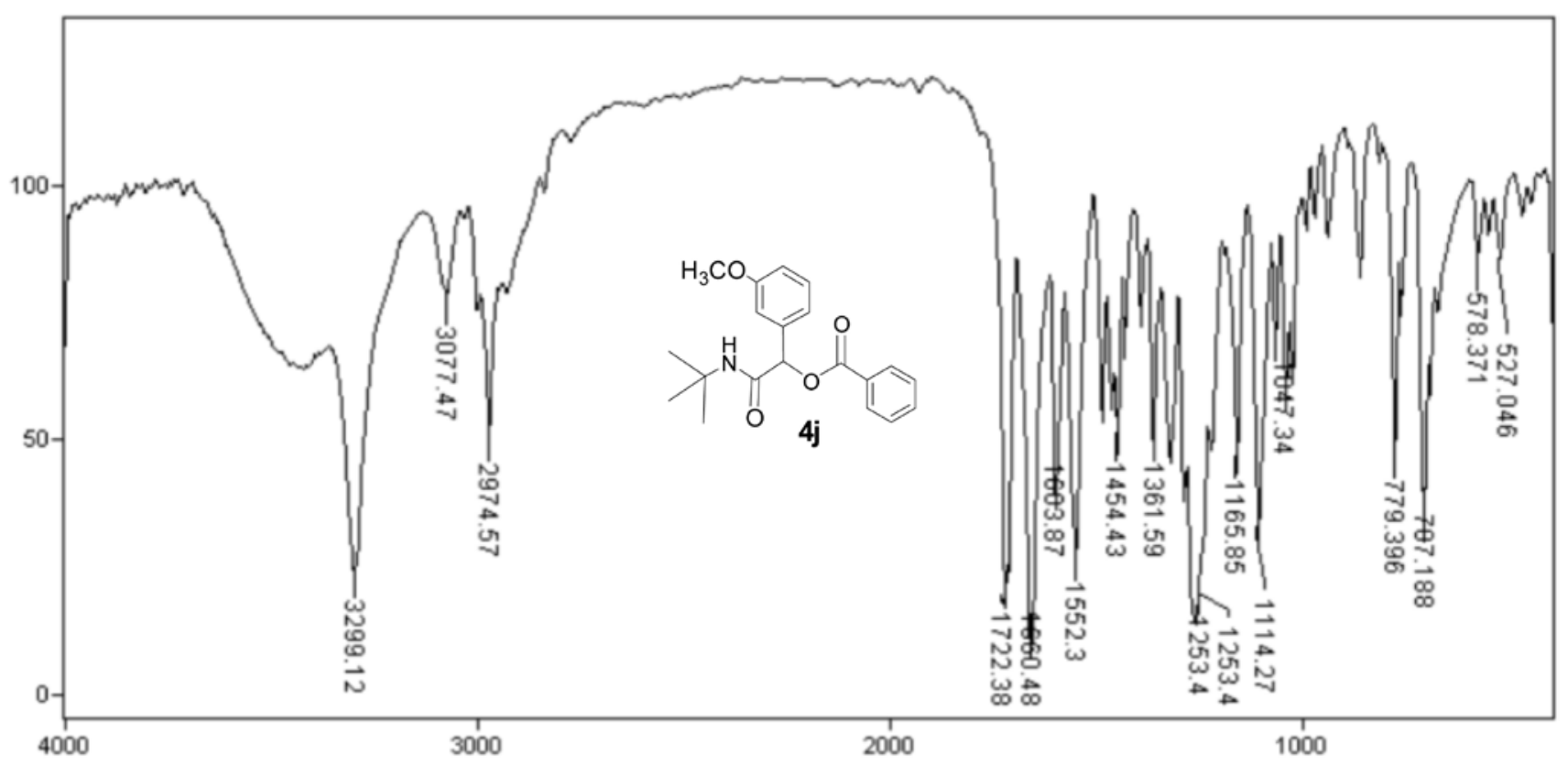

Figure S37. IR spectrum of $\mathbf{4 j}$. 


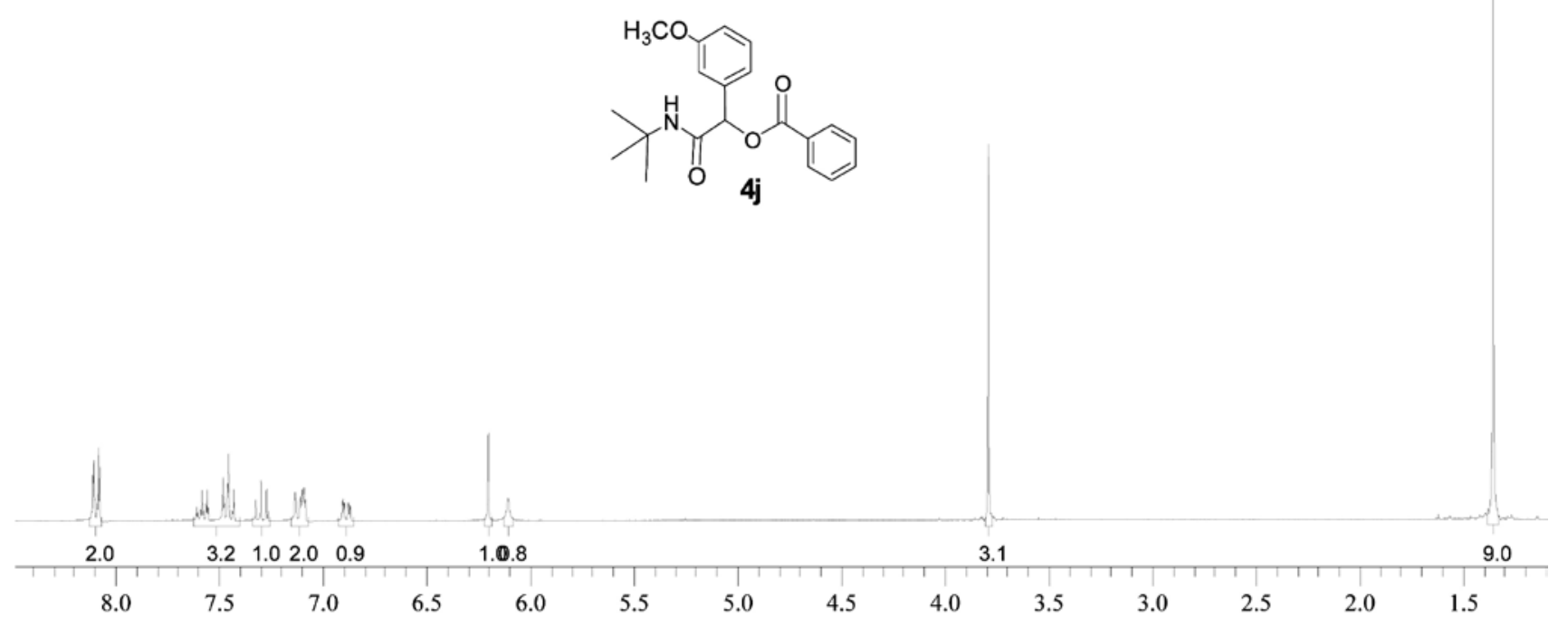

Figure S38. ${ }^{1} \mathrm{H}$ NMR $\left(\mathrm{CDCl}_{3}, 300 \mathrm{MHz}\right)$ of $\mathbf{4 j}$. Note: The number below each peak refers to the number of integration.
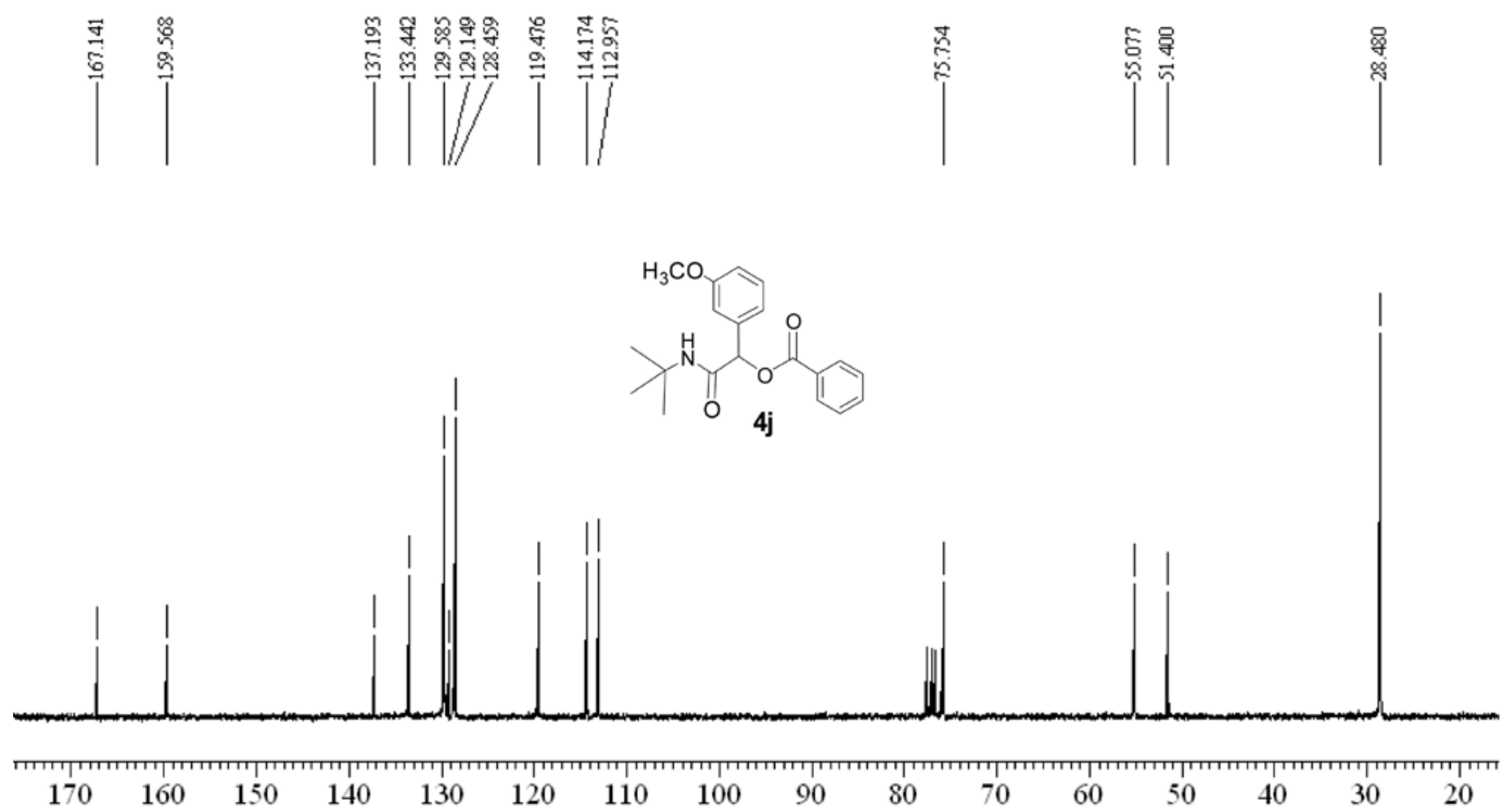

Figure S39. ${ }^{13} \mathrm{C} \mathrm{NMR}\left(\mathrm{CDCl}_{3}, 75 \mathrm{MHz}\right)$ of $\mathbf{4 j}$. 


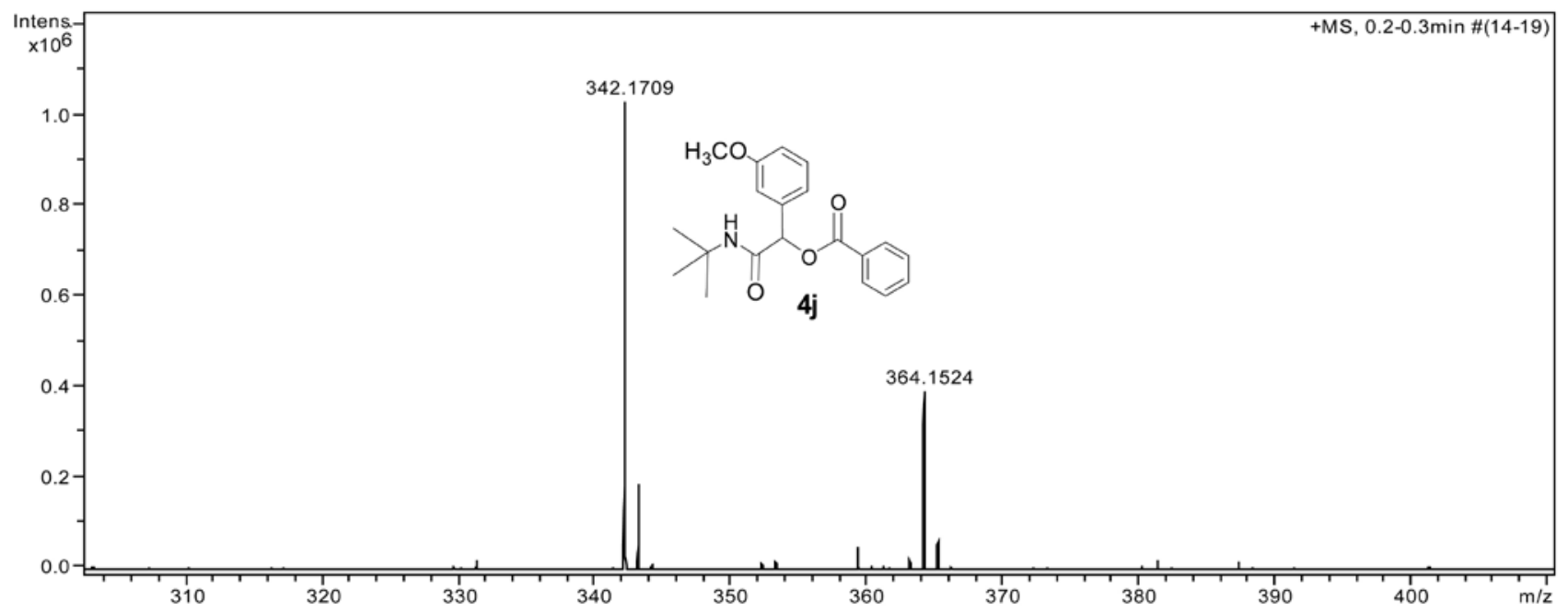

Figure S40. ESI-HRMS of $\mathbf{4 j}$. 